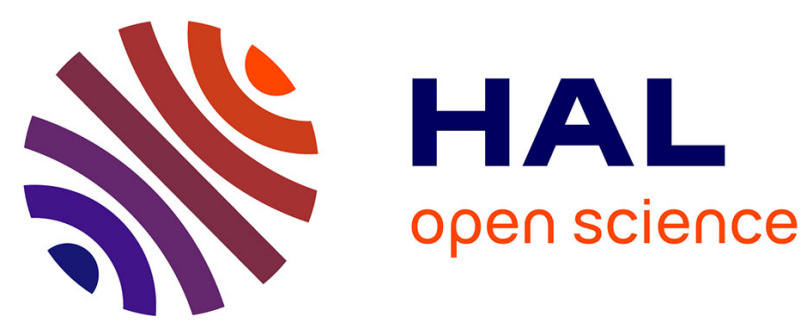

\title{
Late Quaternary Extension Rates Across the Northern Half of the Yadong-Gulu Rift: Implication for East-West Extension in Southern Tibet
}

\author{
M.-l. Chevalier, P. Tapponnier, Jérôme van Der Woerd, Philippe Hervé \\ Leloup, S. Wang, J. Pan, M. Bai, E. Kali, X. Liu, H. Li
}

\section{To cite this version:}

M.-l. Chevalier, P. Tapponnier, Jérôme van Der Woerd, Philippe Hervé Leloup, S. Wang, et al.. Late Quaternary Extension Rates Across the Northern Half of the Yadong-Gulu Rift: Implication for East-West Extension in Southern Tibet. Journal of Geophysical Research: Solid Earth, 2020, 125 (7), 10.1029/2019JB019106 . hal-03012231

\section{HAL Id: hal-03012231 \\ https://hal.science/hal-03012231}

Submitted on 27 Nov 2020

HAL is a multi-disciplinary open access archive for the deposit and dissemination of scientific research documents, whether they are published or not. The documents may come from teaching and research institutions in France or abroad, or from public or private research centers.
L'archive ouverte pluridisciplinaire HAL, est destinée au dépôt et à la diffusion de documents scientifiques de niveau recherche, publiés ou non, émanant des établissements d'enseignement et de recherche français ou étrangers, des laboratoires publics ou privés. 
1 Late Quaternary Extension Rates Across the Northern Half of the Yadong-Gulu

4 M.-L. Chevalier ${ }^{1}$, P. Tapponnier ${ }^{2}$, J. van der Woerd ${ }^{3}$, P. H. Leloup ${ }^{4}$, S. Wang ${ }^{1}$, J. Pan ${ }^{1}$, M.

$5 \quad$ Bai $^{1}$, E. Kali ${ }^{3}$, X. Liu ${ }^{5}$ and H. Li ${ }^{1}$

6

$7{ }^{1}$ Key Laboratory of Deep-Earth Dynamics of Ministry of Natural Resources, Institute of Geology,

8 Chinese Academy of Geological Sciences, 26 Baiwanzhuang Rd, Beijing 100037, People's

9 Republic of China

$10{ }^{2}$ Institute of Crustal Dynamics, China Earthquake Administration, Beijing, People's Republic of

11 China

$12{ }^{3}$ Institut de Physique du Globe de Strasbourg, UMR 7516 CNRS, Universite de Strasbourg, 5 rue

13 René Descartes, 67084 Strasbourg cedex, France

$14{ }^{4}$ Laboratoire de géologie de Lyon, CNRS UMR 5570, Université de Lyon, Villeurbanne, France

$15{ }^{5}$ Institute of Tibetan Plateau Research, Chinese Academy of Sciences, Beijing, China

16

17 Corresponding author: Marie-Luce Chevalier (mlchevalier@hotmail.com)

19 Key points:

20 - Extension rates along Yadong-Gulu rift decrease from north (3-6 mm/yr) to south $(\sim 1.3 \mathrm{~mm} / \mathrm{yr})$

21 due to Beng Co dextral faulting

22 - The post-250 ka extension rate across the $\sim 1000 \mathrm{~km}$ stretch of S Tibet north of Nepal is $9 \pm 2$

$23 \mathrm{~mm} / \mathrm{yr}$, consistent with geodetic rates

24 - The causes and mechanisms of eastward extension south and north of the Bangong-Nujiang suture 
25 are different 


\section{Abstract}

The presence of $\sim$ NS-trending rifts within the Tibetan Plateau attests that it is undergoing $\sim$ EW extension. In southern Tibet, the total extension rate, distributed across seven main rifts over a distance of $\sim 1000 \mathrm{~km}$, has been inferred to amount to about half of the shortening rate across the Himalayas. Quantifying the late Quaternary extension rates across the largest rift (Yadong-Gulu rift: YGR) is important to understand Tibetan deformation and to discuss the high plateau evolution during the later stages of continental collision. We performed ${ }^{10} \mathrm{Be}$ surface-exposure cosmogenic nuclide dating of 57 samples from three fluvial surfaces and two moraines that are vertically offset by the normal faults bounding the northern YGR. After carefully assessing individual ages at each site, to elucidate scatter in the age distributions, we obtained $\sim$ EW extension rates of up to 3-6 $\mathrm{mm} / \mathrm{yr}$ near the northern end of the rift (Gulu) and of only $1.3 \pm 0.3 \mathrm{~mm} / \mathrm{yr}$ in the south (Yangbajing). The fast rates in the north may be influenced by dextral slip along the Beng Co fault, whose rate ought to be at least $6.0 \pm 1.8 \mathrm{~mm} / \mathrm{yr}$. The total late Quaternary extension rate of $9 \pm 2$ $\mathrm{mm} / \mathrm{yr}$ we infer across southern Tibet between $\sim 81$ and $92^{\circ} \mathrm{E}$, assuming similar rates across each rift, is similar to earlier, qualitative inferences, and consistent with recent geodetic results. Distinct deformation rates north and south of the Bangong-Nujiang suture may reflect significant differences between the extensional kinematics and mechanisms across the Qiangtang and Lhasa blocks.

\section{Introduction}

Several deformation mechanisms have been co-involved in accommodating the ongoing convergence of India into Asia: large-scale thrusting along the Himalayas, strike-slip faulting along the edges of, and within the Tibetan Plateau, additional thrusting and crustal thickening yet farther north (Tian Shan, Altai), large and small scale block rotation, and, as long recognized, $\sim \mathrm{EW}$ extension across much of the Tibetan Plateau (e.g., Molnar \& Tapponnier, 1978; Armijo et al., 
1986; Tapponnier et al., 1986; Avouac \& Tapponnier, 1993; Avouac et al., 1993; Peltzer \& Saucier, 1996). However, how much of the $>2000$ km (e.g., Achache et al., 1984; Patriat \& Achache, 1984) of northward penetration of India into Asia has been accommodated by each of these different processes is still debated. Here we try to better quantify the recent $\sim \mathrm{EW}$ extension observed across the series of prominent $\sim$ NS-trending rifts that cut the southern plateau south of the BangongNujiang suture (BNS). Due to remoteness at high elevation and lack of infrastructures, field investigations of the late Quaternary deformation in central Tibet have been few and far apart (e.g., Armijo et al., 1986, 1989; Yin et al., 1999; Blisniuk et al., 2001; Taylor et al., 2003; Ratschbacher et al., 2011; Han et al., 2019; Li et al., 2018). While pioneering studies using satellite imagery and fault plane solutions helped clarify Tibetan faulting patterns on a broad scale (e.g., Molnar \& Tapponnier, 1978; Ni \& York, 1978; Tapponnier et al., 1981; Molnar \& Lyon-Caen, 1989), attempts to quantitatively determine late Quaternary rates along the numerous active normal faults still remain punctual (Blisniuk \& Sharp, 2003; Wu et al., 2004, 2015; Kali, 2010; Chevalier et al., 2012; Ha et al., 2019; Li et al., 2019; Wang et al., 2020).

Early on, Baranowski et al. (1984) and Armijo et al. (1986, 1989) proposed that the dominant $\sim$ EW extension along normal faults bounding $\sim$ NS-trending rifts across southern Tibet was primarily related to divergent, orthogonal thrusting along the curved Himalayan main frontal thrust (MFT), and to the fact that several such rifts branch southwards off active right-lateral strikeslip faults (Figure 1a). These NW-striking, right-lateral strike-slip faults form a dextral, en-echelon array (the Karakorum-Jiali Fault Zone: KJFZ) located along and just south of the BNS, where they all stop. Father north, less prominent, shorter normal faults appear to reflect more widely distributed stretching (e.g., Molnar \& Tapponnier, 1978; Taylor et al., 2003). This suggests that the mechanisms of crustal extension in southernmost Tibet are different from those in west-central Tibet (e.g., Tapponnier et al., 1986). The $\sim 400 \mathrm{~km}$ wide and $\sim 1500-1800 \mathrm{~km}$ long zone of central 
Tibet centered along the BNS has also been interpreted to accommodate coeval EW extension and NS contraction (on order of 10-30 km, hence a small fraction of Indo-Asian convergence) across a series of "conjugate" strike-slip faults with opposite senses (e.g., Wang et al., 2001; Taylor et al., 2003; Yin \& Taylor, 2011). At the whole Plateau scale, the largest "conjugate" strike-slip fault system is that of the Altyn Tagh and Karakorum faults (Figure 1a, inset). The two easternmost, 200-300 km-long faults south of the BNS (Gyaring Co [GCF], Beng Co [BCF] faults, Figure 1a) are the longest of the left-stepping, en-echelon faults within the Karakorum-Jiali fault zone (Armijo et al., 1986). The left-stepping, right-lateral faulting along the KJFZ/BNS shear zone has been suggested to link the Karakorum fault to the west to the Red River and Sagaing faults to the SE (Tapponnier et al., 1986), and to facilitate the eastward extrusion of central Tibet's Qiangtang block (Armijo et al., 1989) (Figure 1a). The Triassic, lithospheric BNS would thus have guided the activation of a younger, neotectonic strike-slip shear zone (Armijo et al., 1986, 1989).

Even though most of the south Tibetan rifts cross the Yarlung Zangbo River and suture (YZS) (as attested for instance by knickpoints where the river crosses the Tangra Yum Co, YadongGulu and Cona-Oiga rifts, Figure 1a, Y. Wang et al., 2019), they are morphologically different to the north and south. To the south, they tend to be less developed, with single, en-echelon master faults in most places (Figure 1a). By contrast, between the YZS and the BNS, the rifts include, or are bounded by, conjugate master faults with larger cumulative throws (e.g., Armijo et al., 1986). This difference north and south of the YZS has been inferred to be related to the presence of strong and cold Indian lithosphere plunging beneath the Tethyan Himalayas. India, however, might not extend far north of the YZS (e.g., Roger et al, 2000; Tapponnier et al., 2001; Liu-Zeng et al., 2008) as sometimes advocated (e.g., Owens \& Zandt, 1997; Tilmann et al., 2003; Copley, 2011).

The presence of normal faulting and EW extension in Tibet have long been correlated with the particularly high elevation of the plateau (e.g., Molnar \& Tapponnier, 1978), which may have 
been attained before the Oligocene in south central Tibet (e.g., Tapponnier et al., 2001; Rowley \& Curie, 2006; DeCelles et al., 2007; Liu-Zeng et al., 2008), and in the middle Miocene in southernmost Tibet (Tethys Himalayas) (e.g., Spicer et al., 2003; Currie et al., 2005; Liu-Zeng et al., 2008; Ding et al., 2017). Divergent orthogonal thrusting (with little or no oblique component) along the curved MFT adequately predicts the average $\sim \mathrm{N} 100^{\circ} \mathrm{E}$ extension direction across southern Tibet (e.g., Baranowski et al., 1984; Armijo et al., 1986, Tapponnier et al., 1986), which is essentially perpendicular to the $\sim \mathrm{N} 6-10^{\circ}$-trending axis of symmetry of the rifts, located between 85 and $88^{\circ}$ E (e.g., Tapponnier et al, 1981; Armijo et al., 1986; Molnar \& Lyon Caen, 1989; Kapp \& Guynn, 2004). Strain partitioning due to oblique convergence between India and Asia, based on Nuvel-1A plate velocities, has also been invoked to account for southern Tibet extension (e.g., Molnar \& Lyon-Caen, 1989; McCaffrey \& Nabelek, 1998; Kapp et al., 2008; Styron et al., 2011; Murphy et al., 2014). Finally, other models argue for convective removal of the Tibetan mantle lithosphere and, following plateau uplift, gravitational collapse and spreading due to maximum sustainable elevation (e.g., England \& Houseman, 1989; Elliott et al., 2010), lithospheric delamination (e.g., Harrison et al., 1992), or even rollback of the east Pacific subduction margin (Yin, 2000).

Constraining the onset and rates of normal faulting along the Tibetan rifts is essential to better understand how Tibet (and other continental plateaus) formed and evolved, as the age of rift initiation may mark a change from compressional thickening to extensional thinning of the crust. The onset of normal faulting may be thought to reflect the time when the Tibetan Plateau was uplifted to its maximum elevation (e.g., Armijo et al., 1986; Garzione et al., 2000). It was initially suggested that rifting, at least in southern Tibet, was very young, starting around $2.0 \pm 0.5 \mathrm{Ma}$, based on the stratigraphic age of late Pliocene/early Quaternary deposits in $\sim$ EW-trending basins north of the Himalayan Range (Armijo et al., 1986). Later chronological studies, however, suggested 
significantly older ages for the onset of extension (up to $\sim 10-14 \mathrm{Ma}$ ) with a rate acceleration in the late Miocene to early Pliocene (4-5 to 8 Ma) (e.g., Mahéo et al., 2007; Lee et al., 2011; Sundell et al., 2013; Styron et al., 2013, 2015). North of the BNS, along the Shuanghu graben, Yin et al. (1999) also inferred an onset age of extension of $<4$ Ma (Figure 1a), later re-assessed to have been much older (13.5 Ma, Blisniuk et al., 2001).

In the south, between the Himalayas and the KJFZ/BNS, southern Tibet is characterized by seven long, $\sim$ NS-trending active rifts (e.g., Molnar \& Tapponnier, 1978; Molnar \& Chen, 1983; Armijo et al., 1986; Molnar \& Lyon-Caen, 1989) that are roughly equally spaced, from $200 \mathrm{~km}$ in the east to $\sim 150 \mathrm{~km}$ in the west. North of the BNS, the more numerous, smaller grabens lie only $\sim 100 \mathrm{~km}$ apart (Armijo et al., 1986). The apparent decrease in rift spacing across the BNS has been suggested to reflect the different mechanical properties of the Lhasa and Qiangtang blocks, a consequence of the different geological histories, thicknesses and ages of their crust (e.g., Hirn et al., 1984; Yin, 2000), which has been shown to vary significantly in different parts of the Tibetan Plateau (e.g., Vergne et al., 2002; Wittlinger et al., 2004). Three of the southern rifts (Thakkhola, Dinggye/Ama Drime and YGR, Figure 1a) radically cross the Himalayan Range. The direction of extension along most rifts and their bounding normal faults $\left(\mathrm{N} 96^{\circ} \mathrm{E} \pm 7^{\circ}\right.$ on average, $\mathrm{N} 102^{\circ} \mathrm{E}$ for the YGR) is perpendicular to the average trend of the rifts N5.9 $\pm 7.5^{\circ} \mathrm{E}$ (Armijo et al., 1986). The longest rift, which is the subject of our study here, the YGR, stretches $\sim 500 \mathrm{~km}$ from the IndiaBhutan border to the BNS north of Gulu, south of Nagqu (Figure 1a).

In this paper, using ${ }^{10} \mathrm{Be}$ surface-exposure cosmogenic isotope dating of vertically offset geomorphic surfaces (two moraines and three alluvial fans and terraces) at five locations along the northern half of the YGR, between the YZS and BNS, we significantly augment the handful of quantitative late Quaternary throw rates that exist in both southern Tibet (three rifts: YGR: Wu et al., 2004; Ha et al., 2019; Wang et al., 2020; Dinggye/Ama Drime rift: Kali, 2010; Gurla 
Mandhata/Pulan rift: Chevalier et al., 2012) and northern Tibet (two rifts: Shuanghu: Blisniuk \& Sharp, 2003; Dong Co: Li et al., 2019). Our data support what Armijo et al. (1986) inferred on a broad scale, i.e., an extension rate of $1.3 \pm 0.3 \mathrm{~mm} / \mathrm{yr}$ along the YGR, consistent with a total of $\sim 9 \pm 2$ $\mathrm{mm} / \mathrm{yr}$ across all seven south Tibetan rifts assuming similar rates across each. This rate is comparable to that predicted by divergent thrusting along the Himalayan arc (Baranowski et al., 1984; Armijo et al., 1986). At a more detailed level, rifting along the Gulu half-graben, northernmost segment of the YGR, may be significantly faster, which may result from interaction with the dextral Beng Co strike-slip fault, part of the KJFZ.

\section{Geological setting of the Yadong-Gulu rift}

Due to its exceptional length $(\sim 500 \mathrm{~km})$ and easy access from Lhasa (Figure 1), the $\mathrm{N} 10^{\circ}$ $35^{\circ}$ E-trending Yadong-Gulu rift (YGR), largest of the south Tibetan grabens has been the focus of significant research (e.g., Armijo et al., 1986, 1989; Harrison et al., 1995; Wu et al., 2004). It is one of the few rifts that cuts across the Himalayan Range, historically allowing trade with India.

Between the China-India (Sikkim) border in the south and Nagqu in the north, the rift crosses major geological structures including the south Tibetan detachment system (STDS, e.g., Burchfiel et al., 1992; Leloup et al., 2010), the Yarlung Zangbo suture (YZS) and river, and terminates just south of the Bangong-Nujiang suture (BNS). From north to south, it can be divided into four parts: 1) the Gulu half-graben, 2) the Damxung corridor north of Yangbajing (Figure 2a), 3) the Yangbajing and Angang grabens between the Nyainqentanghla (NQTL) Range and the Yarlung Zangbo River (Figure 3), and 4) the Yadong grabens south of the Yarlung Zangbo River (Armijo et al., 1986). Roughly $100 \mathrm{~km}$ NW of Lhasa, the NQTL, at $7162 \mathrm{~m}$ one of the highest mountain ranges inside the Tibetan Plateau, extends for about $200 \mathrm{~km}$ in an oblique, northeastern direction (Figure 1b). It follows the west side of the northern YGR, which is bounded by NE to EW-striking normal 
and left-lateral strike-slip faults (Figure 2). While all other active rifts in southern Tibet trend $\sim$ NS and are bounded by predominantly normal faults (e.g., Armijo et al., 1986), the co-existence of active normal and sinistral strike-slip kinematics is unique to the YGR, and is most likely related to inheritance from older, Tertiary tectonic features that now guide the peculiar, oblique, en-echelon geometry of the normal faults (Tapponnier et al., 1981, 1986). Along most of the eastern side of the NQTL Range, slip at the surface is partitioned between two roughly parallel strands having distinct components of motion (strike-slip vs normal), implying shallow bifurcation of oblique slip on the master fault at depth (Armijo et al., 1986).

\subsection{Northern Yadong-Gulu rift: the Damxung corridor - Gulu half-graben}

The northern part of the YGR includes the Damxung corridor and the Gulu half-graben (Figure 2). The $\sim 120 \mathrm{~km}$-long Damxung corridor follows the NE-striking normal-sinistral fault system along the base of the SE slope of the NQTL Range. Numerous Quaternary scarps trending $\mathrm{N} 12^{\circ} \mathrm{E} \pm 7^{\circ}$ form a left-lateral array of east-dipping faults while a few west-dipping faults control the formation of pull-aparts and sag ponds (Armijo et al., 1986). At the Gulu bend, between the Damxung corridor and the Gulu half-graben, the active faults veer $\sim 90^{\circ}$ from an $\sim \mathrm{EW}$ to a $\sim \mathrm{NS}$ direction, in an abrupt transition from dominant left-slip to dominant normal throw (Figure 2a). The western side of the Gulu half-graben is bounded by an east-dipping active normal fault with particularly sharp, steep and high scarps at the base of deeply eroded and gently sloping triangular facets (Figure S1). In most places, the rupture of the 1952, Mw7.4 Gulu earthquake is strikingly clear, with a continuous free-face, up to $\sim 1.5 \mathrm{~m}$-high between the footwall and hanging wall (Tapponnier et al., 1981; Armijo et al., 1986). The normal faults along the northern end of the YGR then connect with the $\sim \mathrm{NW}$-striking, dextral, Beng Co fault rupture (1951 Mw7.7 earthquake, average $8 \pm 2 \mathrm{~m}$ right-lateral coseismic displacement and $90 \mathrm{~km}$-long surface break, Armijo et al., 
1989) (Figures $1 \mathrm{~b}$ and 2).

\subsection{Central Yadong-Gulu rift: the Angang and Yangbajing grabens}

The central part of the YGR is composed of two major NS-trending grabens (Figure 3). To the south, the Angang graben is bounded on its western side by an east-dipping master fault that cuts and offsets a large Quaternary landslide, and along which slickensides attest to normal-sinistral motion (Armijo et al., 1986). The fault bounding the eastern side of the graben is morphologically less prominent, but its stepping segments offset early Holocene terraces (section 5.2, page 19 in Armijo et al., 1986). To the north, the Yangbajing graben, broadest extensional basin along the entire YGR, is filled with up to 1000 m of Quaternary sediments (Cogan et al., 1998). It is limited to the east and west by normal faults dipping steeply in opposite directions (Figure 3). As clearly visible on satellite imagery and in the field, the main, east-dipping normal fault (to the west) exhibits fresh scarps along much of the range-front. Such scarps, along which there are hot springs, follow the base of $\sim 500 \mathrm{~m}$-high triangular facets between hanging glacial valleys (Figure 3) (Armijo et al., 1986; Mercier et al., 1987). An array of closely spaced, sub-parallel, west-dipping normal faults follows the central part of the graben, in rough alignment with both the Damxung corridor to the north and the Angang graben to the south (Armijo et al., 1986; Kapp et al., 2005).

Such faults appear to absorb much of the late Quaternary extension. The west-facing normal escarpments closest to the graben floor are smaller and steeper than those located farther eastwards, which are higher and more eroded, hence likely older. That fault system ruptured during the destructive (due to poorly built adobe houses) 2008 Mw6.3 "Damxung” earthquake, whose hypocenter was $8-12 \mathrm{~km}$ deep, on a $47^{\circ}-53^{\circ}$ west-dipping focal plane (Elliott et al., 2010). At the surface, this event reportedly generated only small landslides and a few cracks (Wu et al., 2011). Towards the north, the dense normal fault array appears to be transversally cut by a sinistral, ENE- 
striking fault that also offsets, by $\sim 4 \mathrm{~km}$, the main, western, range-front fault (Armijo et al., 1986) (Figure 3).

\section{Methods}

To quantitatively determine late Quaternary throw rates along the Yadong-Gulu rift (YGR), we mapped active fault strands and geomorphic surfaces such as alluvial fans, river terraces and glacial moraines, using a combination of field work, high-resolution satellite images, unmanned aerial vehicle (UAV aka drones), as well as high-resolution topographic data from a Riegl VZ1000 terrestrial LiDAR (Light Detection and Ranging) scanner (angular resolution of $0.02^{\circ}$ for raw data, set to $<0.5 \mathrm{~m}$ horizontally and $<0.2 \mathrm{~m}$ vertically between two data points after filtering). We targeted five particularly clear sites along the northern half of the YGR where active faults orthogonally cut and offset geomorphic surfaces, in order to reconstruct the space-time evolution of the faults. Some of these sites (Damxung T, Yangbajing M and Gyekar T) were initially discovered by and discussed in Armijo et al. (1986) and we conducted fieldwork for tectonic (this study) and paleoclimatic (Chevalier et al., 2011a) purposes to complement the earlier, 1986 observations.

Precise vertical (and horizontal) offsets were measured from the Digital Elevation Model (DEM) created by our LiDAR surveys, and the ages of the offset surfaces were deduced from ${ }^{10} \mathrm{Be}$ and ${ }^{26} \mathrm{Al}$ cosmogenic surface-exposure dating (e.g., Lal, 1991; Gosse \& Phillips, 2001). Combining the abandonment age of the surfaces with their offsets yields median throw or horizontal rates on timescales corresponding to the surface ages (calculated using Zechar \& Frankel, 2009). The results are presented in Tables 1 (for moraines) and 2 (for fans/terraces).

Using hammer and chisel, we collected a total of 57 samples from the top few centimeters of large granite boulders ( $>1 \mathrm{~m}$ in diameter) on moraine crests ( $\mathrm{n}=15$ at Gulu M and $n=22$ at $Y$ bj M) and quartzite cobbles ( $20-30 \mathrm{~cm}$ in diameter) on alluvial fans or terraces $(\mathrm{n}=5$ at Gulu $\mathrm{T}, \mathrm{n}=10$ at 
242 Damxung $\mathrm{T}$ and $\mathrm{n}=5$ at Gyekar $\mathrm{T}$ ). The mineral separation and quartz cleaning procedure was modified from Kohl and Nishiizumi (1992). To limit the influence of processes that might have affected the ${ }^{10} \mathrm{Be}$ and ${ }^{26} \mathrm{Al}$ concentration in the samples, with ages appearing younger (due to rolling, erosion or shielding) or older (due to inheritance / prior exposure) than the actual surface ages, we applied corrections for topographic shielding and sampled the largest possible boulders on the moraines and cobbles that were well-embedded in the terrace surfaces. We did not correct for snow (due the lack of regional data) or vegetation (mostly short grass) cover, and we assumed zero erosion when calculating the ages due to the lack of surface incision on the flat terrace surfaces we sampled.

The two moraines studied here (Gulu and Ybj) have been dated by Chevalier et al. (2011a) for paleoclimatic purposes using ${ }^{10} \mathrm{Be}$. We recalculated the corresponding ages using the CRONUS calculator version 2.3 (Balco et al., 2008) with the time-dependent production rate model of Lal (1991)/Stone (2000) for these data as well as for data from the moraines cited here (Owen et al., 2005). We apply Peirce criterion to reject possible outliers then assign a class (A, B or C) according to how well the ages cluster on each moraine using the reduced Chi-squared analysis (e.g., Heyman, 2014; Blomdin et al., 2016; Batbaatar et al., 2018; Chevalier \& Replumaz, 2019). The minimum moraine abandonment age is given by the average age of the samples for class A moraines and by the oldest age for classes B and C moraines (Heyman, 2014; Blomdin et al., 2016).

The quartzite cobbles from the alluvial surfaces were analyzed by Kali (2010) using both ${ }^{10} \mathrm{Be}$ and ${ }^{26} \mathrm{Al}$ cosmogenic isotopes. The ages were recalculated in a way similar to that described above for the moraines. Samples with simple exposure history should have similar ${ }^{10} \mathrm{Be}$ and ${ }^{26} \mathrm{Al}$ ages and $\mathrm{a}^{26} \mathrm{Al} /{ }^{10} \mathrm{Be}$ concentration ratio of 6.1 (Table 2). Departure from this ratio implies that the samples have had a complex exposure history: analytical problems for ratios $>6.1$ and episode(s) of shielding (burial by snow, ice, sediment, or water) and/or erosion for ratios $<6.1$ (Gosse and 
Phillips, 2001). We applied Peirce criterion to alluvial surfaces with more than two samples (which excludes the Gyekar T1 surface) and discuss potential additional outliers following stratigraphic and other observations at each site. Due to the small number of dated samples on each terrace surface, assigning an abandonment age was not straightforward since the Be and $\mathrm{Al}$ ages often vary significantly, with ${ }^{26} \mathrm{Al}$ ages being systematically younger than the ${ }^{10} \mathrm{Be}$ ages (due to the shorter half-life of ${ }^{26} \mathrm{Al}$ ) and since such disparity increases with age (Gosse and Phillips, 2001). Therefore, we present, discuss and interpret each site individually in the following sections.

\section{Site description, results and age interpretation}

\subsection{Gulu moraine}

The Gulu moraine site is located at the outlet of a $8 \mathrm{~km}$-long, U-shaped, glacially incised valley coming from the $6532 \mathrm{~m}$ high Samdain Kangsang peak. The present-day glacier terminus is located $\sim 4 \mathrm{~km}$ upstream from the normal faulted range-front (Figure S1). The normal fault zone crossing this moraine is marked by multiple parallel west- and east-dipping scarps (Figures 4-6 and S2), some of which freshly ruptured by the Mw7.4 1952 Gulu earthquake. That particularly wide ( $\sim 00 \mathrm{~m}$ ) extensional zone forms a smooth graben with a total, cumulative vertical throw depth of $40 \pm 4 \mathrm{~m}$ (Figure 6). The large number of normal fault scarps (up to $\sim 20$, Figures 4-6 and S2), including several with opposite dips, implies distributed extension at shallow depths, in keeping with the fact that most of the cumulative offsets along the faults are comparable and on order of only a few meters (Figure S2). That such active faults do not extend to great depths is clearly visible on both sides of the steep, $\sim 100 \mathrm{~m}$-deep, glacially-incised valley (Figure $4 \mathrm{~b}$ ). On either side of that valley, the normal faults that dip $\sim 50 \pm 10^{\circ}$ on average (Figures 5 and $6 \mathrm{c}$ ) appear to root into a much shallower-dipping detachment, whose intersection with surface topography is visible on both the northern and southern valley flanks (black lines with white polygonal tips in Figure 4). The 
measured, average dip of the detachment surface ranges between $\sim 10^{\circ}$ and $20^{\circ}$ (Figure $4 \mathrm{~b}$ ), roughly parallel to the average dip of the shallow-dipping triangular facets on the bedrock footwall farther upstream in the valley (black lines with green polygonal tips in Figures 4). We thus interpret the widely distributed normal faulting to root at shallow depth on an $18 \pm 5^{\circ}$ east-dipping detachment (green dashed lines in Figure 6c), possibly reactivating an older basement detachment fault exposed on the similarly shallow-dipping facets (Figure S1). Although we did not explore and sample that structure, it may be analogous to the shallow-dipping detachment fault studied in greater details along the southern part of the NQTL Range (e.g., Cogan et al., 1998; Kapp et al., 2005). However, because the epicentral depth of the 1952 Gulu earthquake was most likely on order of $\sim 10-15 \mathrm{~km}$, as is the case for all normal faulting earthquakes in Tibet (e.g., Elliott et al., 2010; Ryder et al., 2014), and because its fault plane and surface rupture had dips between $45-70^{\circ}$ (Armijo et al., 1986), the shallow-dipping detachment fault cannot extend far eastwards past the range-front and must be vertically offset by the more steeply-dipping, seismic normal fault (Figure 6c).

The Gulu moraine surface is covered with short grass and large embedded boulders (Figures 5 and S3). Chevalier et al. (2011a) collected seven samples upstream (T5C-58 to 64) and eight samples downstream (T5C-66 to 73) from the fault along the southern lateral moraine crest (Figure 4b). The ${ }^{10} \mathrm{Be}$ ages range from $16.8 \pm 1.6$ to $22.0 \pm 2.0 \mathrm{ka}$ (Figure 7 and Table 1 ). That age distribution contains no outlier and the moraine is class B (moderately clustered) so that the oldest age is taken to represent the minimum moraine abandonment age. This age closely corresponds to a Last Glacial Maximum age (or Marine Isotope Stage MIS-2) (Clark et al., 2009) and is in agreement with regional studies (e.g., Dong et al., 2014, 2017, Figures 2 and 3). Hence, considering that the $40 \pm 4 \mathrm{~m}$ vertical offset accumulated since that deglaciation time, an average subsidence rate of $1.8 \pm 0.3$ $\mathrm{mm} / \mathrm{yr}$ is obtained. In view of the inferred shallow dip of the basement detachment fault $\left(18 \pm 5^{\circ}\right)$, such a vertical rate would imply an $\sim \mathrm{EW}$ extension rate of $6.0 \pm 1.8 \mathrm{~mm} / \mathrm{yr}$. 
The Gulu terrace site, $15 \mathrm{~km}$ south of the Gulu moraine site (Figure 2), is located at the outlet of a $<2 \mathrm{~km}$-long, V-shaped valley that was only partially glaciated upstream (Figure 8 ). Hence, no glacier crossed the normal fault in the recent past, and a sharp and steep cumulative scarp vertically offsets, by $25 \pm 2 \mathrm{~m}$, a large, flat, fluvial fan at the outlet of that valley (Figure 9). Medium size cobbles rest on top of that fan/terrace surface, which is sparsely covered with short grass (Figures 8 and S4). Just north of the fan, the multiple scarps of the 1952 surface rupture are clearly visible (Figure 8). Southwards, they extend partly along the steepest, free-faced part of the escarpment that limits the fan/terrace to the east. Rockfalls, likely of seismic origin, cover part of the uplifted terrace surface (Figure 8e), while a small village lies on the down-faulted fan surface at the base of the scarp (Figure 8a,f). In order to avoid possible mixing and contamination of fluvial terrace cobbles with colluvium or rockfall debris, we sampled both surfaces as close as possible to the fluvial risers (Figure $8 \mathrm{~b}$ ). We dated three samples upstream and two samples downstream from the fault. The ${ }^{10} \mathrm{Be}$ age distribution from the upper surface are $3.3 \pm 0.3,4.4 \pm 0.5$ and $15.3 \pm 1.5 \mathrm{ka}$, similar to the ${ }^{26} \mathrm{Al}$ age distribution $(2.7 \pm 0.3,3.2 \pm 0.6$ and $12.9 \pm 1.3 \mathrm{ka}$, Figure 10 and Table 2$)$. The two samples on the lower surface yield ${ }^{10} \mathrm{Be}$ ages of $55.1 \pm 5.6$ and $403.1 \pm 42.7 \mathrm{ka}$, and ${ }^{26} \mathrm{Al}$ ages of 43.3 \pm 4.4 and $359.7 \pm 41.2 \mathrm{ka}$. The ${ }^{26} \mathrm{Al} /{ }^{10} \mathrm{Be}$ concentration ratios vary from 4.5 to 5.5 (instead of the ideal 6.1), implying a rather poor agreement between the $\mathrm{Be}$ and $\mathrm{Al}$ measurements, indicative of a complex exposure history (see methods section).

While it is not trivial to reconstruct the deposition history at this site, it is clearly improbable that the upper surface be younger than the lower one. It thus seems likely that the two old ages on the lower surface come from flash flooding of exposed, old bedrock in the upper reaches of the stream catchment (inherited samples/ages). By contrast, the uplifted terrace ages may be interpreted 
to reflect abandonment at $3.4 \pm 0.7 \mathrm{ka}$ (average of the four consistent $\mathrm{Be}$ and $\mathrm{Al}$ ages of the two youngest samples), assuming that the much older ( $\sim 5$ times $)$ age of $15.3 / 12.9 \mathrm{ka}(\mathrm{Be} / \mathrm{Al})$ is an outlier, most likely issued from rock collapse. Using only the more consistent Be ages would yield an age of $3.9 \pm 0.8 \mathrm{ka}$. We note that such an age $(\sim 4 \mathrm{ka})$, as well as the corresponding terrace heights above the present drainage, are consistent with strong river incision following the end of the early Holocene Climatic Optimum (HCO), as frequently observed in and around the Tibetan Plateau (e.g., Gasse et al., 1991; Van der Woerd et al., 2002; Mériaux et al., 2005; Li et al., 2005; Chevalier et al., 2011b, 2012). Combining the $25 \pm 2 \mathrm{~m}$ vertical offset with the $3.9 \pm 0.8 \mathrm{ka}$ age yields a particularly fast throw rate of $6.4(+1.7 /-1.1) \mathrm{mm} / \mathrm{yr}$, in tune with the steep, partly free-faced (60$70^{\circ}$ ), normal fault scarp that bounds the uplifted terrace to the east (Figures $8 \mathrm{f}$ and $9 \mathrm{c}$ ). Given that steep dip, the rate of horizontal extension at this Gulu terrace site would be $3.1 \pm 0.6 \mathrm{~mm} / \mathrm{yr}$. The significant difference with the Gulu moraine site rate, located only $15 \mathrm{~km}$ northwards, would largely be due to the contrasting influence of older tectonic structures. Similar along-strike transitions from high to low-angle normal faulting has been documented elsewhere in Tibet, notably along the Lunggar rift normal faults, to the west (e.g., Kapp et al., 2008; Styron et al., 2013). Here, the difference may be simply interpreted to imply that the deep Gulu master normal fault has breached across the shallow east-dipping detachment and reached the surface.

\subsection{Damxung Terraces}

Farther south near Damxung, in the mid-Damxung corridor, near the gateway of the road to Lake Nam Co, alluvial terraces are offset both horizontally and vertically by combined sinistral and normal faulting. That location was first discovered and described by Armijo et al. (1986; site 18)

(Figures 1b, 2, 11 and 12). At this Damxung Terraces site, an active normal fault branch bounds the NQTL range-front (Figure 11b) while the main fault located farther to the SE splits into two strands 
that vertically offset two large fluvial terrace surfaces by $10 \pm 2 \mathrm{~m}$ (T1) and $184 \pm 3 \mathrm{~m}$ (T2/T1 riser) (Figures 13 and S5), amounts roughly comparable to those (6-8 $\mathrm{m}$ and $\sim 200 \mathrm{~m}$, respectively) proposed by Armijo et al. (1986). On T1, the scarp height along the oblique, strike-slip/normal fault $\mathrm{F} 2$ is larger $(7 \pm 1 \mathrm{~m})$ than that $(3 \pm 1 \mathrm{~m})$ on the mostly normal fault F1 upstream (Figures 12 and 13). Along the downstream strand F2 on T1, a $\sim 5$ m-deep, 270 m-long asymmetric pull-apart basin has formed, a result of perhaps multiple paleo-earthquakes (Figure 12c,d). Similar pull-aparts, some of them larger, exist along both F1 and F2 farther SW (Figure 11b), attesting to left-lateral strike-slip components of motion, in addition to normal faulting. The fact that F1's dip shifts from southward to northward across the western pull-apart over a distance of only a few hundreds of meters confirms its predominantly sub-vertical strike-slip kinematics (Figure 11b), as befits its orientation parallel to all the ENE to EW-striking faults along the Damxung corridor (Figure 2). Finally, the SW edge of T1 is horizontally offset $\sim 17 \pm 5 \mathrm{~m}$ by F2 (Figures $2 \mathrm{e}$ and $11 \mathrm{~d}$ ).

Six embedded cobbles were collected on the surface of T1, which is partly covered with short grass (Figures 11b, 12 and S6). The corresponding ${ }^{10} \mathrm{Be}$ ages cluster well, ranging from $17.8 \pm 1.9$ to $21.0 \pm 2.1 \mathrm{ka}$, with an average of $18.4 \pm 1.4 \mathrm{ka}$. The ${ }^{26} \mathrm{Al}$ ages are in excellent agreement, ranging from $16.6 \pm 1.7$ to $20.8 \pm 2.0 \mathrm{ka}$ (Figure 10 and Table 2), with an identical average age of $18.4 \pm 1.4 \mathrm{ka}$, which we interpret to fix precisely the abandonment age of $\mathrm{T} 1$. This age correlates well with the end of the Last Glacial Maximum, in agreement with warming climate and increased alluvial deposition due to glacial melting. Two of the four samples on the upper T2 terrace yield two ages $\left({ }^{10} \mathrm{Be}\right.$ ages: $4.4 \pm 0.5$ and $16.7 \pm 1.7 \mathrm{ka} ;{ }^{26} \mathrm{Al}$ ages: $4.1 \pm 0.4$ and $7.1 \pm 1.9 \mathrm{ka}$, Figure 10 and Table 2) that are younger than those on T1, and that can therefore be discarded as outliers, inconsistent with local morphology and stratigraphy. The two other samples have much older ${ }^{10} \mathrm{Be}$ ages of $250.2 \pm 26.6$ and $325.2 \pm 35.2 \mathrm{ka}$ and ${ }^{26} \mathrm{Al}$ ages of $198.8 \pm 20.6$ and $283.5 \pm 30.7 \mathrm{ka}$. Although the age scatter is large, the ${ }^{26} \mathrm{Al} /{ }^{10} \mathrm{Be}$ concentration ratios (5.1-5.5) are reasonable. Hence, we take 
the average ${ }^{10} \mathrm{Be}+{ }^{26} \mathrm{Al}$ age of these two samples $(264.4 \pm 53.5 \mathrm{ka})$ to represent the abandonment age of T2. That terrace may have been abandoned during interglacial stages M7 or M9 (Figure 10). Since the $10 \pm 2 \mathrm{~m}$ total vertical offset of T1 across F1 and F2 could only have started to accumulate after $\mathrm{T} 1$ was abandoned at $18.4 \pm 1.4 \mathrm{ka}$, the corresponding throw rate across both faults is $0.5 \pm 0.1 \mathrm{~mm} / \mathrm{yr}$. Combining the $184 \pm 3 \mathrm{~m}$ vertical offset of the T2/T1 riser with the age difference ( $\sim 246 \mathrm{ka})$ between the two yields a minimum throw rate of $>0.75 \pm 0.2 \mathrm{~mm} / \mathrm{yr}$. A similar rate $(\sim 0.76$ $\mathrm{mm} / \mathrm{yr}$ ) is obtained using the age of T2 and its height above the river. Note that combining the $\mathrm{T} 2 / \mathrm{T} 1$ riser offset with the age of $\mathrm{T} 1$ would yield an implausibly fast maximum throw rate of $\sim 10$ $\mathrm{mm} / \mathrm{yr}$. The left-lateral slip-rate along F2, deduced from the $17 \pm 5 \mathrm{~m}$ horizontal offset and the age of $\mathrm{T} 1$, is $0.9 \pm 0.3 \mathrm{~mm} / \mathrm{yr}$. The normal throw rates near Damxung ( $\sim 0.5$ to $0.75 \mathrm{~mm} / \mathrm{yr})$ are significantly slower than those found to the north, near Gulu ( 1.8 and $6.4 \mathrm{~mm} / \mathrm{yr})$. This, however, may be largely due to the fact that slip here is partitioned between normal and sinistral faulting. Using a fault dip of $70^{\circ}$ (Armijo et al., 1986) with a rake of $22^{\circ}$ on F2 (Figure S7), and adding both the F1 and $\mathrm{F} 2$ throw rates $(4.5$ and $6.5 \mathrm{~m}$ in $18.4 \mathrm{ka}=0.24$ and $0.35 \mathrm{~mm} / \mathrm{yr}$, respectively) to the $\mathrm{F} 2$ sinistral rate $(0.9 \mathrm{~mm} / \mathrm{yr})$ yields a combined extension rate of $<1.6 \mathrm{~mm} / \mathrm{yr}$ in the $\mathrm{N} 80^{\circ} \mathrm{E}$ direction (Figure S7). Note also that movement on the range-front fault (Figure 11b), which appears to still be active, would further increase the total extension rate.

\subsection{Yangbajing (Ybj) moraines}

The Ybj moraines (site 12 in Armijo et al., 1986) are located at the outlet of a small hanging glacial valley along the west side of the Yangbajing graben, whose spectacularly normal faulted edge is bounded by prominent triangular facets (Figures 1,3, and 14). The glacial valley is about 5 $\mathrm{km}$-long, and the modern glacial terminus is located about $3 \mathrm{~km}$ west of the fault. Along the normal fault, the lateral moraines are cut by a fresh, 5-6 m-high scarp $\left(37^{\circ}\right.$ slope, Figure $\left.14 \mathrm{e}, \mathrm{g}\right)$ that may 
410 have been the result of a single large earthquake that produced a continuous surface rupture of at

411 least $\sim 10 \mathrm{~km}$-long (Armijo et al., 1986). That earthquake might have been temporarily related to the 412 great M8.0 (?), 1411 Damxung earthquake surface break (Figure 1b), whose surface rupture has 413 been interpreted to extend fart northwards along much of the Damxung corridor, over a total length 414 of $\sim 136 \mathrm{~km}$ (Wu et al., 1992). On both sides of the glacial valley, the lateral moraine surfaces are 415 covered with short grass and with large, embedded granite boulders (Figure S8). Our LiDAR measurements show that the normal fault sharply cuts and vertically offsets the moraines by $44 \pm 1 \mathrm{~m}$ (Figure 15), a value much less than that of the cumulative offset of the valley floor ( $\geq 150 \mathrm{~m}$ ) estimated by Armijo et al. (1986).

Chevalier et al. (2011a) collected 10 samples on both the upstream (T5C-25 to 34) and downstream (T5C-35 to 44) crests of the southern moraine, and two samples on the upstream northern moraine crest (T5C-44bis and 45) (Figure 14b). These sample ages range from $18.8 \pm 1.8$ to 56.1 $\pm 5.4 \mathrm{ka}$ (Figure 7 and Table 1). That age distribution contains no outliers and the moraine is class C (poorly-clustered). Such a scattered but continuous age distribution is typical of moraines older than the Last Glacial Maximum (LGM $\sim 20 \mathrm{ka}$ ), due to progressive exhumation of buried boulders by erosion of the moraine matrix, which yields ages younger than the actual moraine age (Chevalier \& Replumaz, 2019). Thus, the oldest age suggests a Marine Isotope Stage MIS-3 age for the moraine abandonment, in agreement with the age of other outer moraines from southern and western Tibet (e.g., Chevalier et al., 2011a). Chevalier et al. (2011a) also collected five samples (T5C-19 to 23) on an inner moraine crest located upstream from the fault (Figure 14b) whose recalculated oldest age after rejecting one outlier $(22.3 \pm 2.1 \mathrm{ka})$ using Peirce criteria is $15.8 \pm 1.5 \mathrm{ka}$ $(\mathrm{n}=4,12-15.8 \mathrm{ka}$, Table 1). However, this rejection of the oldest outlier would mean an absence of LGM moraine in this valley while it is clearly present at Gulu and elsewhere along the NQTL Range (Dong et al., 2014, 2017, Figures 2 and 3) and must therefore be taken with caution. In any 
case, a LGM (or younger) age is in agreement with that crest's position within the outer MIS-3 moraine. Combining the $44 \pm 1 \mathrm{~m}$ vertical offset with the outer moraine's oldest age yields a vertical throw rate of $0.8 \pm 0.1 \mathrm{~mm} / \mathrm{yr}$. Given the steepest dip of the normal fault escarpment $\left(\sim 41^{\circ}\right.$, Figure $15 \mathrm{~b})$, this would be consistent with a maximum extension rate of $0.9 \pm 0.1 \mathrm{~mm} / \mathrm{yr}$.

\section{5 Gyekar site}

On the SE side of the Yangbajing graben, alluvial fans and terraces at the Gyekar site (site 11 in Armijo et al., 1986) are vertically offset by numerous $\mathrm{N} 12^{\circ} \pm 16^{\circ}$ E-trending, west-dipping normal faults, resulting in a peculiar staircase morphology (Figures 1, 3, 16 and 17). These terraces and faults are transversally cut by partly glacier-fed rivers, with incision deep enough to expose normal fault planes with slickensides in cross-sections (Tapponnier et al., 1981). In contrast with drainage in the northern Yangbajing basin, all the rivers flowing into the southern part of the basin feed a central endoreic marshy wetland (Figure 3). Numerous small gullies, incising deeper across the higher fault scarps, sometimes reach the terrace surfaces (Figure 17b,d). These surfaces are covered with short grass and medium-size cobbles (Figures 17 and S9). The T1/T0 escarpment attests to a cumulative vertical offset of $15 \pm 3 \mathrm{~m}$ by normal fault $\mathrm{F} 1$, while that of T2/T1, due to movement on $\mathrm{F} 2$, is as much as $\sim 6$ times larger $(87 \pm 5 \mathrm{~m})$ (Figure $18 \mathrm{~b})$.

We dated two samples on T1 and four on T2 (Figure 16b). The two cobbles on $\mathrm{T} 1$ yield ${ }^{10} \mathrm{Be}$ ages of $68.1 \pm 6.8$ and $178.0 \pm 18.5 \mathrm{ka}$ and ${ }^{26} \mathrm{Al}$ ages of $64.3 \pm 6.9$ and $154.8 \pm 16.6 \mathrm{ka}$ (Figure 10 and Table 2), that are unfortunately insufficient to ascertain a precise abandonment age. The four cobbles on T2 yield three similar ${ }^{10} \mathrm{Be}$ ages $(218,252$ and $277 \mathrm{ka})$ and two similar ${ }^{26} \mathrm{Al}$ ages (193 and $196 \mathrm{ka}$ ), an average of $227.2 \pm 36.4 \mathrm{ka}$, with the remaining three ages being much younger (98, 39 and $14 \mathrm{ka}$ ) (Figure 10 and Table 2). We interpret the much younger ages as outliers since T2, which is uplifted six times higher than T1, must necessarily be much older. For the same reason, the 
younger, ${ }^{10} \mathrm{Be}$ and ${ }^{26} \mathrm{Al}$ ages on $\mathrm{T} 1$ (68 and $64 \mathrm{ka}$, average of $66.2 \pm 2.7 \mathrm{ka}$ ) may be taken to represent the most plausible abandonment age of T1. Within uncertainties, such ages ( $\sim 66$ and $227 \mathrm{ka})$ are consistent with interstadials (MIS-4 and 7) during which a warmer, wetter climate would have favored river incision whereas by contrast, colder and drier glacial periods limit river flow and thus restrict incision and terrace abandonment.

Combining the $15 \pm 3 \mathrm{~m}$ vertical offset of $\mathrm{T} 1$ with its inferred abandonment age $(66.2 \pm 2.7 \mathrm{ka})$ would yield a vertical throw rate of $\sim 0.2 \pm 0.1 \mathrm{~mm} / \mathrm{yr}$ on F1. Similarly, combining the $102 \pm 5 \mathrm{~m}$ total vertical offset of T2 with its abandonment age $(227.2 \pm 36.4 \mathrm{ka})$ would yield a throw rate of $0.4 \pm 0.1$ $\mathrm{mm} / \mathrm{yr}$ on F2. The cumulative throw rate on both active normal faults would thus be on order of $0.6 \pm 0.2 \mathrm{~mm} / \mathrm{yr}$, which might still be a minimum since there are numerous other small, likely active fault strands east and west of the Gyekar site along the east side of the southern Yangbajing basin. Note, however, that older faults (away from the basin) might tend to become inactive as younger ones (towards the basin) develop (e.g., Sanchez et al., 2010), which would make the contribution of $\mathrm{T} 1$ and $\mathrm{T} 2$ to regional extension the dominant ones.

We did not collect quantitative data along the active, east-dipping normal fault that bounds the western side of the southern Yangbajing graben, along which hot springs are aligned at the base of large triangular facets (Figures 3 and 17c,i). However, we infer that its throw rate may be similar to that on the Ybj moraine fault $(0.8 \pm 0.1 \mathrm{~mm} / \mathrm{yr})$ along the west side of the northern Yangbajing graben, consistent with the similar height $(\sim 1600 \mathrm{~m})$ of the mountain range it bounds above the graben floor. The $55 \pm 1^{\circ}$ dip of $\mathrm{F} 1$ between $\mathrm{T} 1$ and $\mathrm{T} 0$ and the $65 \pm 1^{\circ}$ dip of $\mathrm{F} 2$ between $\mathrm{T} 2$ and $\mathrm{T} 1$, both of which precisely measured in the field (Figures 16 and 17f,g), and similar to that derived from the 2008 Mw6.3 "Damxung” earthquake co-seismic InSAR data (54.4 W, Liu et al., 2012), yield a minimum extension rate on the eastern side of the Yangbajing graben of $0.3 \pm 0.1 \mathrm{~mm} / \mathrm{yr}$. This results in a total minimum extension rate of $1.2 \pm 0.2 \mathrm{~mm} / \mathrm{yr}(0.9$ of extension at $\mathrm{Ybj} \mathrm{M}+0.3$ 
$\mathrm{mm} / \mathrm{yr}$ ) across the southern Yangbajing graben.

\section{Discussion}

5.1 Review of previous late Quaternary throw rates determination along the south Tibetan grabens

Prior to the widespread use of cosmogenic dating, Armijo et al. (1986) had inferred an onset age of extension across the south Tibetan graben normal faults of $\sim 2.0 \pm 0.5 \mathrm{Ma}$, based on paleontological, stratigraphic and geomorphic observations. Combining such ages with cumulative throws (3-5 km for the YGR, $2.0 \pm 0.6 \mathrm{~km}$ for other rifts) implied a minimum long-term geological throw rate of $1.0 \pm 0.6 \mathrm{~mm} / \mathrm{yr}$ on most graben's master faults, and of $1.9 \pm 0.6 \mathrm{~mm} / \mathrm{yr}$ (\#6b in Figure 19a and Table 3) along the YGR where tectonic relief is the largest. Along the western side of the Yangbajing graben, Armijo et al. (1986) also suggested late Quaternary throw rates of $\sim 1.6 \mathrm{~mm} / \mathrm{yr}$ (\#6a in Figure 19a and Table 3), based on the inference that the offset glacial moraines formed after the last interstadial at $60 \mathrm{ka}$ (inferred $100 \mathrm{~m}$ vertical offset in $60 \mathrm{ka}$, site Ybj moraines). However, taking the Ybj moraines offset to be only $44 \mathrm{~m}$ would be consistent with a throw rate of only 0.8 $\mathrm{mm} / \mathrm{yr}$.

Overall, the late Quaternary throw rates we obtain and discuss here vary from north to south between $1.8 \pm 0.3 \mathrm{~mm} / \mathrm{yr}$ (Gulu moraines 'GM'), 6.4(+1.7/-1.1) mm/yr (Gulu terraces 'GuT'), $0.5 \pm 0.1$ - $0.75 \pm 0.2 \mathrm{~mm} / \mathrm{yr}$ (Damxung terraces 'DT'), $0.8 \pm 0.1 \mathrm{~mm} / \mathrm{yr}(Y b j$ moraines 'YM') and 0.6 $\pm 0.2 \mathrm{~mm} / \mathrm{yr}$ (Gyekar terraces 'GyT') (Figure 19a and Table 3). Our results are particularly robust at the Gulu moraine and Damxung terraces sites due to precise offset measurements and tightly clustered ages. This is corroborated by the fact that our Gulu moraine ${ }^{10} \mathrm{Be}$ age (recalculated at $22.0 \pm 2.0 \mathrm{ka}, \mathrm{n}=15$, Chevalier et al., 2011a) is identical, within error, to that (recalculated at 21.7 $\pm 2.2 \mathrm{ka}, \mathrm{n}=8$, Owen et al., 2005, class B) of another moraine in the next valley to the south after the oldest sample age 
$(42.6 \pm 4.2 \mathrm{ka})$ was discarded using Peirce criterion.

At the late Quaternary timescale, relatively few recent studies have specifically targeted quantitative measurements of throw rates along south Tibetan normal faults. In the Pulan graben, on the west side of the Gurla Mandhata (Figure 1a), Chevalier et al. (2012) determined a minimum throw rate of $1.6 \pm 0.4 \mathrm{~mm} / \mathrm{yr}$ using ${ }^{10} \mathrm{Be}$ cosmogenic dating (34 $\left.\pm 7 \mathrm{ka}\right)$ of vertically offset $(53 \pm 5 \mathrm{~m})$ alluvial surfaces. A maximum rate of $1.9(+0.8 / 0.5) \mathrm{mm} / \mathrm{yr}$ was obtained with a lower terrace offset by $15 \pm 1 \mathrm{~m}$ in $8.0 \pm 2.5 \mathrm{ka}$. Using the same technique, Kali (2010) measured vertical throw rates of $\sim 1.2$ and $\sim 1.7 \mathrm{~mm} / \mathrm{yr}$ along the western (Kharta) and eastern (Dinggye) normal faults bounding the Ama Drime horst along the Dinggye/Ama Drime graben (Figure 1a), respectively. Along the northern YGR, Wu et al. (2004, 2015) used electron spin resonance (ESR), optically stimulated luminescence (OSL) and U-series dating of vertically offset alluvial surfaces to constrain normal throw rates. Rates of $1.4 \pm 0.6 \mathrm{~mm} / \mathrm{yr}$ during the Holocene and of $1.1 \pm 0.3 \mathrm{~mm} / \mathrm{yr}$ during the Quaternary (\#7a and \#7ab in Figure 19 and Table 3, respectively) were obtained in the Yangbajing graben (Wu et al., 2004), and of 0.8-1.3 mm/yr (\#8) in the Angang graben (Wu et al., 2015). Most of these values correlate well with those we determine here. Finally, along the southern YGR, vertical throw rates of $0.7 \pm 0.1 \mathrm{~mm} / \mathrm{yr}$ (\#9, Ha et al., 2019) and of $0.9 \pm 0.3 \mathrm{~mm} / \mathrm{yr}$ (\#10, Wang et al., 2020) have recently been constrained using OSL and ${ }^{10} \mathrm{Be}$ cosmogenic dating, respectively.

Overall, the combination of these results suggest that late Quaternary/Holocene throw rates across most grabens south of the Bangong-Nujiang suture (BNS) may be similar and on order of $\sim 1$ to $2 \mathrm{~mm} / \mathrm{yr}$. By contrast, north of the BNS, across the prominent Shuanghu rift, significantly slower late Quaternary throw rates $<0.3 \mathrm{~mm} / \mathrm{yr}$ in the last $233 \mathrm{ka}$, and of $0.2-0.3 \mathrm{~mm} / \mathrm{yr}$ in the last $120 \mathrm{ka}$ have been obtained using U-series dating of pedogenic carbonates (Blisniuk \& Sharp, 2003) and ${ }^{10}$ Be surface-exposure cosmogenic dating (Pan et al., 2018), respectively. Although these latter results are of narrow regional extent, they tend to support the geomorphic/topographic-based 
inference that the kinematics of normal faulting north and south of the BNS is different.

\subsection{Extension rates along the northern Yadong-Gulu rift}

From north to south, the late Quaternary extension rates we determine here vary between $6.0 \pm 1.8 \mathrm{~mm} / \mathrm{yr}$ (Gulu moraines), $3.1 \pm 0.6 \mathrm{~mm} / \mathrm{yr}$ (Gulu terraces), $<1.6 \mathrm{~mm} / \mathrm{yr}$ (Damxung terraces), and a total of $1.2 \pm 0.2 \mathrm{~mm} / \mathrm{yr}$ across the southern Yangbajing graben $(0.9 \pm 0.1 \mathrm{~mm} / \mathrm{yr}$ at $\mathrm{Ybj}$ moraines $+0.3 \pm 0.1 \mathrm{~mm} / \mathrm{yr}$ at Gyekar terraces) (Figure 19), i.e., 3-6 mm/yr north of the Gulu bend and $1.3 \pm 0.3 \mathrm{~mm} / \mathrm{yr}$ south of it. While the average rates we obtain between Damxung and Gyekar are in fair agreement with those inferred earlier (Armijo et al., 1986), and with those measured along a few other south Tibetan rifts (Wu et al., 2004, 2015; Kali, 2010; Chevalier et al., 2012; Ha et al., 2019; Wang et al., 2020), the rate we determine closer to Gulu (north of the $90^{\circ}$ Gulu bend) are not, in keeping with the particularly spectacular and youthful tectonic morphology initially noted by Armijo et al. (1986, 1989).

Taken at face value, such rates appear to increase sharply and rapidly northwards, specifically north of the Gulu bend (Figure 19b). We infer that such faster rates might result from a transfer of slip from the Beng Co dextral fault to the Gulu normal fault, the latter absorbing a significant part of the displacement along the former (Armijo et al., 1986, 1989). If this were the case, the present-day slip-rate on the Beng Co fault would be at least $6.0 \pm 1.8 \mathrm{~mm} / \mathrm{yr}$. Right-lateral late Quaternary slip-rates as fast as $10-20 \mathrm{~mm} / \mathrm{yr}$ have been inferred along that fault (Armijo et al., 1989; Peltzer \& Saucier, 1996), while geodetic, InSAR-based rates have been shown to be between $1 \pm 1$ and $4 \pm 1 \mathrm{~mm} / \mathrm{yr}$ (Garthwaite et al., 2013), $<6 \mathrm{~mm} / \mathrm{yr}$ (Taylor \& Peltzer, 2006), and $7.7 \mathrm{~mm} / \mathrm{yr}$ (Ryder et al., 2014). Recent, ongoing deformation in this region of the Plateau is quite complex, as it combines movements on large normal faults, on long, conjugate, strike-slip faults, and tectonic uplift of several of Tibet's highest (>7000 m) mountain ranges (Figure 1b). While the origin of such 
complexity is still poorly understood, it likely reflects significant changes in deformation kinematics since the early Tertiary (e.g., Tapponnier et al., 1986; Harrison et al., 1995). Along the Gulu half-graben, for instance, shallow extension is taken up either by a single, steep normal fault or by widely distributed extensional faults dipping in opposite directions. Southwards near Damxung, deformation is partitioned between normal and sinistral motion along two roughly parallel faults that likely merge at depth (Armijo et al., 1986). The strike of both faults is at highangle to that of the Beng Co and Jiali dextral faults (Figures 1b, 2 and S1). Finally, although the particularly high elevation of the Nyainqentanghla (NQTL) Range, the steep slope of its NW, $61^{\circ}$ trending range-front, and the presence, along that front, of strongly deformed and folded Cretaceous red beds, may be taken to imply NW-directed Tertiary overthrusting (e.g., Tapponnier et al., 1986; Armijo et al., 1989), consistent with the steep bathymetric gradient along the SE shore of Lake Nam Co (e.g., Kasper et al., 2012), while the more gentle SE side of the NQTL Range exposes a shallowdipping detachment (e.g., Cogan et al., 1998; Kapp et al., 2005).

By statistically averaging the strikes of active normal faults, Armijo et al. (1986) proposed average extension directions of $\mathrm{N} 102^{\circ} \mathrm{E}$ across the $\mathrm{YGR}$ and of $\sim \mathrm{N} 96^{\circ} \mathrm{E} \pm 7^{\circ}$ across most of the south Tibetan rifts. Both directions are perpendicular to the average rift trends $\left(\mathrm{N} 6-10^{\circ} \mathrm{E}\right)$ and to their bounding normal faults. They are also comparable to the average $\mathrm{T}$ axes of regional earthquake focal mechanisms in central/southern Tibet (e.g., Molnar \& Lyon-Caen, 1989; Zhu et al., 2017; Wu et al. 2019). Field morphological measurements, outcrop exposures and slickenside data (Tapponnier et al., 1981; Armijo et al., 1986; Mercier et al., 1987) constrain active normal fault dips to range between $45^{\circ}$ and $60^{\circ}$ (up to $70^{\circ}$ near Damxung, Figure S7). Accordingly, based on the throw rate of $1.9 \pm 0.6 \mathrm{~mm} / \mathrm{yr}$ they estimated, Armijo et al. (1986) determined an $\sim \mathrm{EW}$ extension rate across the northern half of the YGR of $1.4 \pm 0.8 \mathrm{~mm} / \mathrm{yr}$. Most of the robust dip angle values recently obtained using InSAR and body-wave data for instrumental earthquakes along the YGR and 
Pumqu-Xainza rifts (e.g., Elliott et al., 2010; H. Wang et al., 2014) are also consistent with steep (41 to $52^{\circ}$ ) fault planes. Finally, our own field measurements of the two exposed normal fault planes at Gyekar document steep dips of $55 \pm 1$ and $65 \pm 1^{\circ}$ (Figures $16 \mathrm{~b}$ and $17 \mathrm{f}, \mathrm{g}$ ). In summary, despite the influence of a locally complex tectonic history, our quantitative offset/dip/age measurements along the YGR in the Yangbajing graben constrain $\sim$ EW extension rates on fairly steep, $41-70^{\circ}$ dipping normal faults to be slightly in excess of $1 \mathrm{~mm} / \mathrm{yr}$, with a sharp northwards increase, by a factor of $\sim 5$, near the Beng Co-Jiali dextral fault.

With the exception of our Gulu results, possibly influenced by strike-slip "drag”, along the Beng Co-Jiali fault zone, the $1.3 \pm 0.3 \mathrm{~mm} / \mathrm{yr}$ average extension rate we find is similar to, while more precise than, the rate $(1.4 \pm 0.8 \mathrm{~mm} / \mathrm{yr})$ inferred by Armijo et al. (1986). Assuming, as justified by presently available data across some other rifts and by their similar morphologies and widths, comparable extension rates across each of the six other main south Tibetan rifts (from $\sim 81$ to $\sim 92^{\circ} \mathrm{E}$ ) with negligible active normal faulting between them, we obtain a total, active extension rate of $9 \pm 2 \mathrm{~mm} / \mathrm{yr}$ across southern Tibet south of the BNS, while the above authors' broader estimate was $10 \pm 5.6 \mathrm{~mm} / \mathrm{yr}$. The south Tibetan rifts do show differences in geometry, symmetry, and amounts of total exhumation (e.g., Kapp et al., 2008; C. Wang et al., 2014; Styron et al., 2015; Wolff et al., 2019), but it is clear on high-resolution topographic maps and satellite images that from a morphological standpoint, their present-day widths and depths (a measure of active crustal stretching amounts) are fairly similar. Thus, in the absence of comprehensive, quantitative late Quaternary studies across all other rifts, we take our simple estimate of $9 \pm 2 \mathrm{~mm} / \mathrm{yr}$ to best reflect the present-day, southern Tibet extension rate. This value is significantly smaller than that estimated by Molnar and Lyon-Caen (1989) $\left(18 \pm 9 \mathrm{~mm} / \mathrm{yr}\right.$ in a more southeasterly $\mathrm{N} 115^{\circ} \mathrm{E}$ direction), using the total seismic moment release due to earthquakes between 1962 and 1986 (24 years). By contrast, using InSAR data from normal faulting earthquakes in the last 43 years (1966 
to 2008), a time interval almost twice as long, Elliott et al. (2010) estimated a much slower rate (3-4 $\mathrm{mm} / \mathrm{yr}$ in the EW direction). Besides potential disparities in the EW length of the region considered, such large differences are most likely due to different observation time spans, unknown earthquake recurrence intervals, and event clustering. The $9 \pm 2 \mathrm{~mm} / \mathrm{yr}$ total extension rate is comparable to that predicted by divergent thrusting along the Himalayan arc (Baranowski et al., 1984; Armijo et al., 1986), which requires that the $\sim$ EW extension rate across southern Tibet should be about half that of underthrusting of rigid India beneath the Himalayan Range. All recent estimates of central transHimalayan shortening across the whole length $(\sim 1000 \mathrm{~km})$ of Nepal (e.g., Holocene average of $21 \pm 1.5 \mathrm{~mm} / \mathrm{yr}$, Lavé \& Avouac, 2000; GPS average of $19 \pm 2.5 \mathrm{~mm} / \mathrm{yr}$ in central and eastern Nepal, Bettinelli et al, 2006; or $15.5 \pm 2 \mathrm{~mm} / \mathrm{yr}$, Lindsey et al., 2018) do support an extension rate across southernmost Tibet on order of $\sim 10 \pm 1 \mathrm{~mm} / \mathrm{yr}$ (i.e., half of $\sim 20 \mathrm{~mm} / \mathrm{yr}$ ). Even the latter, slowest convergence would still be in keeping with $\sim 8 \pm 1 \mathrm{~mm} / \mathrm{yr}$ of extension.

As an incentive for future research, note that a $\sim 9 \mathrm{~mm} / \mathrm{yr}$ total extension rate would be comparable to the maximum right-lateral slip-rate determined along the Karakorum fault (Chevalier et al., 2005, 2012), and might be taken to imply a comparable right-lateral slip-rate along the Jiali fault, which likely connects with the NE Sagaing fault south of the Putao pull-apart basin (Figure 27 in Armijo et al., 1989).

\subsection{Comparison with geodetic rates}

Early GPS studies with a limited number of stations across Tibet (Wang et al., 2001; Zhang et al., 2004) suggested a total extension rate of $\sim 20-22 \mathrm{~mm} / \mathrm{yr}$ between $\sim 79^{\circ}$ and $\sim 93^{\circ} \mathrm{E}$. The recent, wholesale East Asia GPS dataset of Zheng et al. (2017) suggests a uniformly distributed extension rate of $\sim 15 \mathrm{~mm} / \mathrm{yr}$ across all of southern Tibet $(\sim 1500 \mathrm{~km})$. Taking the shorter distance (only $\sim 1000$ $\mathrm{km}$ ) between the westernmost (Gurla Mandhata) and easternmost (Cona) rifts that limit the area we 
consider (Figure 1a) would yield a rate of $\sim 10 \mathrm{~mm} / \mathrm{yr}$, similar to the $9 \pm 2 \mathrm{~mm} / \mathrm{yr}$ southern Tibet extension rate we propose. The GPS/InSAR joint inversion results of Wang et al. (2019) suggest a total $\sim 15 \mathrm{~mm} / \mathrm{yr}$ of EW extension across south-central Tibet (between 80 and $92^{\circ} \mathrm{E}$ ). According to these authors, the Lopu Kangri rift (northward extent of the Thakkhola rift), the Tangra Yum Co rift, and the YGR would absorb similar amounts of extension (4-5 mm/yr each, \#1 in Figure 19a and Table 3). The Pumqu-Xainza rift (Figure 1a), on the other hand, would absorb only 1-2 mm/yr (Wang et al., 2019).

Other GPS studies, such as that of Chen et al. (2004a,b), suggested a total extension rate of $9.7 \pm 3.0 \mathrm{~mm} / \mathrm{yr}$ across all rifts, with $\sim 6 \mathrm{~mm} / \mathrm{yr}$ across the YGR (\#2 in Figure 19a and Table 3), and much of the rest $(\sim 4 \mathrm{~mm} / \mathrm{yr})$ across the Thakkhola graben, even though their GPS estimates encompass a broader area than that constrained by geological studies, a potential source of discrepancies. Note that the YGR and Thakkhola rifts, were singled out by Replumaz and Tapponnier (2003) to be the most active of all south Tibetan rifts, in the last 5 Ma. Compatible GPS values of $5.2 \pm 0.4$ and $7.8 \pm 0.4 \mathrm{~mm} / \mathrm{yr}$ across the same two rifts were obtained by Wang et al. (2017) (\#3). Interestingly, it is also along these two rifts (Lopu Kangri/Thakkhola and YGR) that the greatest number of $\mathrm{M}>6$ earthquakes have occurred north of the Yarlung Zangbo suture (YZS) in the last 40 years (Figure 1a). Later GPS studies (Gan et al., 2007) found a $2.0 \pm 0.6 \mathrm{~mm} / \mathrm{yr}$ extension rate across the YGR (\#4), roughly consistent with that inferred by Armijo et al. (1986) (1.4 \pm 0.8 $\mathrm{mm} / \mathrm{yr})$ and with our own rate south of the Gulu bend $(1.3 \pm 0.3 \mathrm{~mm} / \mathrm{yr})$, as well as a left-lateral strike-slip rate of $0.7 \pm 1.1 \mathrm{~mm} / \mathrm{yr}$, also in keeping with our left-lateral slip-rate near Damxung $(0.9 \pm 0.3 \mathrm{~mm} / \mathrm{yr})$. Finally, in a recent 3D micro-block kinematic model, Tian et al. (2019) used geodetic and seismic observations to infer an extension rate of $5.6 \pm 0.8 \mathrm{~mm} / \mathrm{yr}$ in the northern YGR (\#5 in Figure 19a and Table 3), which would be consistent with our faster local result. However, their model also yields a right-lateral slip-rate component of $1.4 \pm 0.9 \mathrm{~mm} / \mathrm{yr}$ in the same area, while 
the NE-trending active transfer segment between Yangbajing and Gulu unquestionably entails a significant component of left-lateral faulting.

\subsection{Implications for present-day Tibetan deformation}

Armijo et al. (1986) suggested that the 'chord' between the eastern and western Himalayan syntaxes, which appears to guide localized, en-echelon, right-lateral shear roughly along the older BNS, separates two regions with different deformation regimes (Figure 20). To the north (between the Altyn Tagh fault and the BNS, Figure 1a), dominant strike-slip faulting earthquakes occur within the Qiangtang block (e.g., Molnar \& Tapponnier, 1978; Molnar \& Chen, 1983; Molnar \& Lyon-Caen, 1989; Zhu et al., 2017; Wu et al., 2019), which is free to move eastwards. With the exception of the large strike-slip events close to the Karakorum-Jiali Fault Zone (KJFZ), along the Beng Co (BCF), Gyaring Co (GCF) and Damxung faults (1951, Mw7.7; 1934, M 7; and 1411, $\mathrm{M} \sim 8$, respectively) (Figure 1a), normal faulting earthquakes predominate across the Lhasa block (between the BNS and the Yarlung Zangbo suture), which is restrained to the east and west by the two Himalayan Syntaxes (Armijo et al., 1986). Hence, prevailing sinistral strike-slip faulting in central Tibet north of the BNS likely reflects the eastwards extrusion of the Qiangtang block mostly along the Gyaring Co and Beng Co faults (e.g., Peltzer \& Tapponnier, 1988; Wu et al., 2011; Han et al., 2019), while the Lhasa block to the south extends as a result of divergent orthogonal thrusting along the Main Frontal Thrust (e.g., Baranowski et al, 1984; Armijo et al., 1986) (Figure 20). Other models have inferred a significant role of underthrusting of Indian lower crust beneath the plateau (e.g., DeCelles et al., 2002; Styron et al., 2015) and/or of oblique convergence (mostly in the western Himalaya, Styron et al., 2011; Murphy et al., 2014). That faulting north and south of the BNS results from different processes is consistent with the much smaller strike-slip displacements inferred along the NE-striking central Tibet sinistral faults $(\sim 10-20 \mathrm{~km}$, Taylor et al., 2003; Yin \& 
Taylor, 2011) than along the dextral Karakorum fault (>120 km offset of the Indus River, e.g., Gaudemer et al., 1989; Robinson, 2009; and >250 km geological offset, Matte et al., 1996; Lacassin et al., 2004; Valli et al., 2007).

\subsection{Recent seismicity and long-term return times}

Up to 14 earthquakes with M>6 (EDPDCEA earthquake catalogs, 1999), 12 of which between the Yarlung Zangbo and the Bangong-Nujiang sutures, occurred along or near the YadongGulu rift (YGR) prior to the 2008 Mw6.3 "Damxung" earthquake near Gyekar. The oldest and largest known events are the 1264 Yangyi M6.7, and the 1411 Damxung-Yangbajing M8 (?) earthquakes. The latter is inferred to have produced $\sim 136 \mathrm{~km}$ of surface rupture, with maximum vertical and horizontal displacements of 8-9 and 11-13 m, respectively, between Damxung and Yangbaijing (Wu et al., 1992). All the other events postdate the advent of instrumental seismology at the end of the $19^{\text {th }}$ century. They include the 1901 North Nimu (Nyemo?) M6.8 earthquake, the 1924 Nimu M6 earthquake, the 1924 Yalin graben (west of Yangbaijing) M6.5 earthquake, the 1951-1952 Beng Co/Gulu Mw7.7-7.4 earthquake sequence (with $\sim 90 \mathrm{~km}$ of surface ruptures, Armijo et al., 1989), and the 1992 Nyemo Mw6.1 earthquake (Figure 1b). The remaining seismic gap between the Angang and the Yangbaijing grabens was apparently partly filled by the 2008 earthquake. Liu et al. (2012) suggested an earthquake recurrence interval along the southern Yangbajing graben (also called Yangyi graben) of 744 years, based on the time elapsed between the 1264 and the 2008 events. Assuming that the last event released all the accumulated strain, they inferred a long-term slip-rate of $\sim 1.8 \mathrm{~mm} / \mathrm{yr}$, derived from the InSAR-based seismic slip (1.33 m) and the recurrence interval (744 years). Note that this value would imply an extension rate of $\sim 1$ $\mathrm{mm} / \mathrm{yr}$ across only the eastern side of the southern Yangbaijing graben. It would thus be roughly consistent with the loosely constrained values estimated across the whole graben by Armijo et al. 
(1986) (1.4 $\pm 0.8 \mathrm{~mm} / \mathrm{yr})$ and Gan et al. (2007) $(2.0 \pm 0.6 \mathrm{~mm} / \mathrm{yr})$. On the other hand, it would be larger than the minimum value we obtain $(0.3 \pm 0.1 \mathrm{~mm} / \mathrm{yr})$ on just the graben's eastern side. Only one large earthquake (M8?, 1411) is inferred to have ruptured the entire length of the $\sim 150 \mathrm{~km}$-long Damxung corridor (Wu et al., 1992). Although six M5+ events occurred during the first half of the $19^{\text {th }}$ century near the NE tip of the corridor (Figure 1b), one of which possibly an aftershock of the 1951 sequence, the major part of the fault inferred to have ruptured in 1411 shows no field evidence of a very fresh, modern surface rupture, including on high-resolution satellite images. Using the rates we determined between Damxung and Gulu ( $\sim 1.6$ to $6 \mathrm{~mm} / \mathrm{yr})$ and the time elapsed since the last large event (608 years) would yield a slip deficit of 1-4 m, much smaller than the co-seismic horizontal slip values (11-13 m) inferred for the 1411 event. Thus, a return of a comparatively large event in this part of the rift is not expected in the foreseeable future. but it is clear that paleoseismologic and additional detailed geomorphic dating are needed between Damxung and Gulu to assess the return times of very large earthquakes similar to the 1411 and 1951-1952 events.

\section{Conclusion}

After a careful discussion of the individual ${ }^{10} \mathrm{Be}$ and ${ }^{26} \mathrm{Al}$ cosmogenic surface-exposure ages we obtained on each of the two moraines and three alluvial surfaces, that are vertically offset by active normal faults along the northern Yadong-Gulu rift (YGR), most prominent of the seven $\sim$ NStrending rifts in southern Tibet, we quantitatively determined throw and extension rates along that rift between the Yarlung Zangbo (YZS) and Bangong-Nujiang (BNS) sutures. Extension rates are found to rapidly decrease southwards from $6.0 \pm 1.8$ and $3.1 \pm 0.6 \mathrm{~mm} / \mathrm{yr}$ north of the $90^{\circ} \mathrm{Gulu}$ bend, to an average of $1.3 \pm 0.3 \mathrm{~mm} / \mathrm{yr}$ south of it. The fast rates to the north are in fair agreement with regional geodetic (GPS and InSAR) measurements. We interpret the change to reflect partial 
transfer of slip southwards from the right- lateral Beng Co fault, whose slip-rate should thus not be less than $6 \mathrm{~mm} / \mathrm{yr}$. Our late Quaternary average rate south of the Gulu bend is comparable to other quantitatively constrained rates along other south Tibetan rifts south of the BNS ( $\sim 1$ to $2 \mathrm{~mm} / \mathrm{yr}$ ). Such rates appear faster than the few measured rates $(<0.3 \mathrm{~mm} / \mathrm{yr})$ north of the BNS, consistent with the geomorphic and topographic differences on either side of that suture. Even though additional quantitative data from other south Tibetan rifts remain crucial to better constrain a total, regional extension rate between $\sim 81$ an $\sim 92^{\circ} \mathrm{E}$, assuming a similar average rate $(1.3 \pm 0.3 \mathrm{~m} / \mathrm{yr})$ across each of the seven south Tibetan grabens between the Gurla Mandhata/Pulan and Cona rifts ( $\sim 1000 \mathrm{~km}$ apart) yields a total $\sim \mathrm{EW}$ extension rate of $9 \pm 2 \mathrm{~mm} / \mathrm{yr}$. This value is comparable to, albeit on the lower side of estimates based on the use of geodetic data across the same $\sim$ EW stretch of southern Tibet. It amounts to about half of the total convergence rate (between 14 and $21 \mathrm{~mm} / \mathrm{yr}$ ) between India and Asia along Nepal's Himalayan Main Frontal Thrust, and is thus consistent with a simple model of divergent, orthogonal thrusting of southern Tibet atop a rigid Indian plate.

\section{Acknowledgements}

This project was financially supported by the CNRS-INSU-DyETI 2004-83, the National Key Research and Development Project of China (2016YFC0600310), the 2nd Tibetan Plateau Scientific Expedition of the Ministry of Science and Technology of China (2019QZKK0901), the Natural National Science Foundation of China (NSFC 41672211, 41672210), the China Geological Survey (DD20190057, DD20190059), the Basic Research Funds of the Institute of Geology, CAGS (JYYWF201810, JYYWF201821), and the European Marie Sklodowska-Curie Outgoing International Fellowship FP6 (040070) to MLC. We thank Robin Lacassin and Peiquan Zhang for their help in the field. All data from this paper are presented in Tables 1 and 2. We are grateful to the Associate Editor P. DeCelles and to J.E. Saylor and K. Sundell for their detailed and insightful 
reviews.

\section{References}

Achache, J., Courtillot, V., \& Zhou, Y. (1984), Paleogeographic and tectonic evolution of southern Tibet since Middle Cretaceous time: New paleomagnetic data and synthesis. Journal of Geophysical Research, 89, B12, doi:10.1029/JB089iB12p10311.

Armijo, R., Tapponnier, P., Mercier, J. L., \& Han, T. L. (1986), Quaternary extension in southern Tibet: Field observations and tectonic implications. Journal of Geophysical Research, 91, $13,803-13,872$.

Armijo, R., Tapponnier, P., \& Tonglin, H. (1989), Late Cenozoic right-lateral strike-slip faulting in southern Tibet. Journal of Geophysical Research, 94, 2787 - 2838.

Avouac, J.P., \& Tapponnier, P. (1993), Kinematic model of active deformation in central Asia. Geophysical Research Letters, 20, 895-898.

Avouac, J.P., Tapponnier, T., Bai, M., You, H., \& Wang, G. (1993), Active thrusting and folding along the northern Tien Shan and Late Cenozoic rotation of the Tarim relative to Dzungaria and Kazakhstan. Journal of Geophysical Research, 98, 6755-6804, doi:10.1029/92JB01963.

Balco, G., Stone, J. O., Lifton, N. A., \& Dunai, T. J. (2008), A complete and easily accessible means of calculating surface exposure ages or erosion rates from ${ }^{10} \mathrm{Be}$ and ${ }^{26} \mathrm{Al}$ measurements. Quaternary Geochronology, 3 (3), 174-195. doi:10.1016/j.quageo.2007.12.001.

Batbaatar, J., Gillespie, A. R., Fink, D., Matmon, A., \& Fujioka, T. (2018),

Asynchronous glaciations in arid continental climate. Quaternary Science Reviews, $182,1-19$.

Baranowski, J., Armbruster, J., Seeber, L. \& Molnar, P. (1984), Focal depths and fault plane 
solutions of earthquakes and active tectonics of the Himalaya. Journal of Geophysical Research, 89, 6918-6928.

Bettinelli, P., Avouac, J.P., Flouzat, M., Jouanne, F., Bollinger, L., Willis, P., \& Chitrakar, G.R., (2006), Plate motion of India and interseismic strain in the Nepal Himalayan from GPS and DORIS measurements. Journal of Geodesy, 80, 567-589.

Blisniuk, P., Hacker, B., Glodny, J., Ratschbacher, L., Bi, S., Wu, Z. et al. (2001), Normal faulting in central Tibet since at least 13.5 Myr ago. Nature, 412, $628-632$.

Blisniuk, P.M., \& Sharp, W.D. (2003), Rates of late Quaternary normal faulting in central Tibet from U-series dating of pedogenic carbonate in displaced fluvial gravel deposits. Earth and Planetary Science Letters, 215(1 - 2), 169-186.

Blomdin, R., Stroeven, A. P., Harbor, J. M., Lifton, N. A., Heyman, J., Gribenski, N., et al. (2016), Evaluating the timing of former glacier expansions in the Tian Shan: a key step towards robust spatial correlations. Quaternary Science Reviews, 153, 78-96, doi:10.1016/j.quascirev.2016.07.029.

Burchfiel, B. C., Chen, Z., Hodges, K. V., Liu, Y., Royden, L. H., Deng, C. \& Xu, J. (1992), The South Tibetan Detachment System, Himalayan orogen: Extension contemporaneous with and parallel to shortening in a collisional mountain belt. Special Paper Geological Society of America, 269, 41 pp.

Chen, Q., Freymueller, J. T., Yang, Z., Xu, C., Jiang, W., Wang, Q., \& Liu, J. (2004a), Spatially variable extension in southern Tibet based on GPS measurements. Journal of Geophysical Research, 109(B09401). doi:10.1029/2002JB002350.

Chen, Q., Freymueller, J. T., Wang, Q., Yang, Z., \& Xu, C. (2004b). A deforming block model for the present-day tectonics of Tibet. Journal of Geophysical Research, 109(B01403). doi:10.1029/2002JB002. 
Chevalier, M.-L., Ryerson, F. J., Tapponnier, P., Finkel, R. C., Van Der Woerd, J., Haibing, L., \& Qing, L. (2005), Slip-rate measurements on the Karakorum fault may imply secular variations in fault motion. Science, 307, 411-414. doi:10.1126/science.1105466.

Chevalier, M.-L., Hilley, G., Tapponnier, P., Van Der Woerd, J., Liu-Zeng, J., Finkel, R. C., et al. (2011a), Constraints on the late Quaternary glaciations in Tibet from cosmogenic exposure ages of moraine surfaces. Quaternary Science Reviews, 30 (5-6), 528-554. doi:10.1016/j.quascirev.2010.11.005.

Chevalier, M.L., Li, H., Pan, J., Pei, J., Wu, F., Xu, W., Sun, Z., \& Liu, D. (2011b), Fast slip-rate along the northern end of the Karakorum fault system, Western Tibet. Geophysical Research Letters, 38, L22309, doi:10.1029/2011GL049921.

Chevalier, M.-L., Tapponnier, P., Van der Woerd, J., Ryerson, F. J., Finkel, R., \& Li, H. (2012), Spatially constant slip rate along the southern segment of the Karakorum fault since $200 \mathrm{ka}$. Tectonophysics, 530/531, 152-179. doi:10.1016/j.tecto.2011.12.014.

Chevalier, M.-L., \& Replumaz, A. (2019), Deciphering old moraine age distributions in SE Tibet showing bimodal climatic signal for glaciations: Marine Isotope Stages 2 and 6. Earth and Planetary Science Letters, 507, 105-118. doi:10.1016/j.eps1.2018.11.033.

Clark, P. U., Dyke, A. S., Shakun, J. D., Carlson, A. E., Clark, J., Wohlfarth, B., et al. (2009), The Last Glacial Maximum. Science, 325, 710-714. doi:10.1126/science.1172873.

Cogan, M. J., Nelson, K . D., Kidd, W. S. F., Wu, C., \& Project INDEPTH Team (1998), Shallow structures of the Yadong- Gulu Rift, southern Tibet, from refraction analysis of Project INDEPTH common midpoint data. Tectonics, 17, 46-61.

Copley, A., Avouac, J. P. \& Wernicke, B. P. (2011), Evidence for mechanical coupling and strong Indian lower crust beneath southern Tibet. Nature, 472(7341), 79-81.

Currie, B.S., Rowley, D.B., \& Tabor, N.J. (2005), Middle Miocene paleoaltimetry of southern 
Tibet: implications for the role of mantle thickening and delamination in the Himalayan orogen. Geology, 33, 181-84

DeCelles, P., Robinson, D., \& Zandt, G. (2002), Implications of shortening in the Himalayan foldthrust belt for uplift of the Tibetan Plateau. Tectonics 21, 6, 1062, doi:10.1029/2001TC001322.

DeCelles, P., Quade, J., Kapp, P., Fan, M., Dettman, D., \& Ding, L. (2007), High and dry in central Tibet during the Late Oligocene. Earth and Planetary Science Letters, 253, 389-401.

Ding, L., Spicer, R.A., Yang, J., Xu, Q., Cai, F., Li, S., et al. (2017), Quantifying the rise of the Himalaya orogen and implications for the South Asian monsoon. Geology, 45, 215-218.

Dong G., Yi, C., \& Caffee, M. W. (2014), ${ }^{10}$ Be dating of boulders on moraines from the last glacial period in the Nyainqentanglha mountains, Tibet. China Earth Sciences, 57, 221-231.

Dong, G., Xu, X., Zhou, W., Fu, Y., Zhang, L., \& Li, M. (2017), Cosmogenic ${ }^{10}$ Be surface exposure dating and glacier reconstruction for the last glacial maximum in the quemuqu valley, western Nyainqentanglha mountains, south Tibet. Journal of Quaternary Science, $32,639-652$.

Earthquake Disaster Prevention Department of China Earthquake Administration (EDPDCEA) (1999), Catalogue of historical earthquakes in China. Earthquake Press, Beijing, China. (In Chinese).

Elliott, J. R., Walters, R. J., England, P. C., Jackson, J. A., Li, Z., \& Parsons, B. (2010), Extension on the Tibetan Plateau: Recent normal faulting measured by InSAR and body wave seismology. Geophysical Journal International, 183(2), 503-535.

England, P., \& Houseman, G. (1989), Extension during continental convergence, with application to the Tibetan plateau. Journal of Geophysical Research, 94, 17,561 - 17,579.

Fielding, E., Isacks, B., Barazangi, M., \& Duncan, C. (1994), How flat is Tibet? Geology, 22, 163- 
Gan, W., Zhang, P., Shen, Z., Niu, Z., Wang, M., Wan, Y., \& Cheng, J. (2007), Present-day crustal motion within the Tibetan Plateau inferred from GPS measurements. Journal of Geophysical Research, 112(B08416). doi:10.1029/2005JB004120.

Garthwaite, M. C.,Wang, H., \& Wright, T. J. (2013), Broadscale interseismic deformation and fault slip rates in the central Tibetan Plateau observed using InSAR. Journal of Geophysical Research, 118, 5071-5083. doi:10.1002/jgrb.50348.

Garzione, C. N., Dettman, D. L., Quade, J., DeCelles, P. G., \& Butler, R. F. (2000), High times on the Tibetan Plateau: Paleoelevation of the Thakkola graben, Nepal. Geology, 28, 339-342, doi:10.1130/0091-7613(2000)28@339:HTOTTP2.0.CO;2.

Gasse, F., Arnold, M., Fontes, J. C., Fort, M., Gibert, E., Huc, A., et al. (1991), A 13,000 year climate record from Western Tibet. Nature, 353, 742-745.

Gaudemer, Y., Tapponnier, P., \& Turcotte, D. L. (1989), River offsets across active strike slip faults. Annales Tectonicae, 3(2), 55-76.

Gosse, J., \& Phillips, F. (2001), Terrestrial in situ cosmogenic nuclides: theory and application. Quaternary Science Reviews, 20, 1475-1560.

Ha, G., Wu, Z., \& Liu, F. (2019), Late Quaternary vertical slip rates along the Southern YadongGulu Rift, Southern Tibetan Plateau. Tectonophysics, 755, 75-90. doi:10.1016/j.tecto.2019.02.014.

Han, S., Li, H., Pan, J., Lu, H., Zheng, Y., Liu , D., \& Ge, C. (2019), Co-seismic surface ruptures in Qiangtang Terrane: Insight into Late Cenozoic deformation of central Tibet. Tectonophysics, 750, 359-378. doi:10.1016/j.tecto.2018.11.001.

Harrison, T. M., Copeland, P., Kidd, W. S. F., \& Yin, A., (1992), Raising Tibet. Science, 255, $1663-1670$. 
Harrison, T. M., Copeland, P., Kidd, W. S., \& Lovera, O. M. (1995), Activation of the Nyainqentanghla shear zone: Implications for uplift of the southern Tibetan Plateau. Tectonics, 14, $658-676$.

Heyman, J. (2014), Paleoglaciation of the Tibetan Plateau and surrounding mountains based on exposure ages and ELA depression estimates. Quaternary Science Reviews, 91, 30-41. doi:10.1016/j.quascirev.2014.03.018.

Hirn, A., Nercessian, A., Sapin, M., Jobert, G., Xu, Z., Gao, E., et al. (1984), Lhasa block and bordering sutures-A continuation of $500 \mathrm{~km}$ Moho traverse through Tibet. Nature, 307, 25 27, 1984.

Kali, E. (2010), De la déformation long-terme à court-terme sur les failles normales du Sud-Tibet: approche géochronologique multi-méthode (10Be, 26Al, (U-Th)/He, 40Ar/39Ar, U/Pb, 0361., PhD thesis, EOS Strasbourg, France.

Kapp, P., \& Guynn, J.H. (2004), Indian punch rifts Tibet. Geology, 32, 993-996.

Kapp, J. L., Harrison, T. M., Kapp, P., Grove, M., Lovera, O. M., \& Lin, D. (2005), Nyainqentanglha Shan: A window into the tectonic, thermal, and geochemical evolution of the Lhasa block, southern Tibet. Journal of Geophysical Research, 110(B08413). doi:10.1029/2004JB003330.

Kapp, P., Taylor, M., Stockli, D., \& Ding, L. (2008) Development of active low-angle normal fault systems during orogenic collapse: Insight from Tibet. Geology, 36, 7-10.

Kasper T, Haberzettl T, Doberschutz S. et al. (2012), Indian Ocean Summer Monsoon (IOSM)dynamics within the past 4 ka recorded in the sediments of Lake Nam Co, central Tibetan Plateau (China). Quaternary Science Reviews, 39: 73-85.

Kohl, C.P., \& Nishiizumi, K. (1992), Chemical isolation of quartz for measurement of in situ produced cosmogenic nuclides. Geochimica et Cosmochimica Acta, 56, 3583-3587. 
Lacassin, R., Valli, F., Arnaud, N., Leloup, P. H., Paquette, J. L., Li, H., Tapponnier, P., et al. (2004), Large-scale geometry, offset and kinematic evolution of the Karakorum fault, Tibet. Earth and Planetary Science Letters, 219, 255-269. doi:10.1016/S0012-821X(04)00006-8.

Lal, D. (1991), Cosmic ray labeling of erosion surfaces: in situ nuclide production rates and erosion models. Earth and Planetary Science Letters, 104, 429-439.

Lavé, J. \& Avouac, J. P. (2000), Active folding of fluvial terraces across the Siwaliks Hills, Himalayas of central Nepal. Journal of Geophysical Research, 105, 3, 5735-5770, doi:10.1029/1999JB900292.

Lee, J., C. Hager, S. R. Wallis, D. F. Stockli, M. J. Whitehouse, M. Aoya, \& Y. Wang (2011), Middle to late Miocene extremely rapid exhumation and thermal reequilibration in the Kung Co rift, southern Tibet. Tectonics, 30, TC2007, doi:10.1029/2010TC002745.

Leloup, P. H., Mahéo, G., Arnaud, N., Kali, E., Boutonnet, E., Liu, D., et al. (2010), The South Tibet detachment shear zone in the Dinggye area Time constraints on extrusion models of the Himalayas. Earth and Planetary Science Letters, 292, 1-16.

Li, H., Van der Woerd, J., Tapponnier, P., Klinger, Y. Qi, X., Yang, J., \& Zhu Y., (2005), Slip rate on the Kunlun fault at Hongshui Gou, and recurrence time of great events comparable to the 14/11/2001, Mw 7.9 Kokoxili earthquake. Earth and Planetary Science Letters, 237, 285-299.

Li, K., Wang, D., Shao, Q., \& Xu, X., (2018), Holocene sip rate along the NE-trending Qixiang Co fault in the central Tibetan Plateau and its tectonic implications. Seismology and Geology, 40 (6). doi:10.3969/j.issn.0253-4967.2018.06.002.

Li, K., Kirby, E., Xu, X., Chen, G., Ren, J., \& Wang, D. (2019), Rates of Holocene normal faulting along the Dong Co fault in central Tibet, based on 14C dating of displaced fluvial terraces. Journal of Asian Earth Sciences, doi:10.1016/j.jseaes.2019.103962. 
914 Lindsey, E. O., Almeida, R., Mallick, R., Hubbard, J., Bradley, K., Tsang, L. L. H., et al. (2018), Structural control on downdip locking extent of the Himalayan megathrust. Journal of Geophysical Research, 123, 5265-5278. doi:10.1029/2018JB015868.

Lisiecki, L.E., \& Raymo, M.E. (2005), A Pliocene-Pleistocene stack of 57 globally dis-tributed benthic $\delta 180$ records. Paleoceanography, 20 (1). doi:10.1029/2004PA001071.

Liu,Y., Xu, C., Wen, Y., He, P., \& Jiang, G. (2012), Fault rupture model of the 2008 Dangxiong (Tibet, China) Mw 6.3 earthquake from Envisat and ALOS data. Advances in Space research, 50, 952-962. doi:10.1016/j.asr.2012.06.006.

Liu-Zeng, J., Tapponnier, P., Gaudemer, Y., \& Ding, L. (2008), Quantifying landscape differences across the Tibetan plateau: Implications for topographic relief evolution. Journal of Geophysical Research, 113, F04018, doi:10.1029/2007JF000897.

Mahéo, G., Leloup, P. H., Valli, F., Lacassin, R., Arnaud, N., Paquette, J.-L., et al. (2007), Post 4 Ma initiation of normal faulting in southern Tibet. Earth and Planetary Science Letters, 256, 233-243. doi:10.1016/j.epsl.2007.01.029.

Matte, P., Tapponnier, P., Arnaud, N., Bourjot, L., Avouac, J.P., Vidal, P., Liu, Q., Pan, Y., and Wang, Y. (1996), Tectonics of western Tibet, between the Tarim and the Indus. Earth and Planetary Science Letters, 142, 311-330, doi: 10 .1016/0012 -821X (96)00086 -6 .

McCaffrey, R., \& Nabelek, J. (1998), Role of oblique convergence in the active deformation of the Himalayas and southern Tibet plateau. Geology, 26, 691-694.

Mercier, J. L., Armijo, R., Tapponnier, P., Carey-Gailhardis, E. \& Han, T. (1987), Change from Tertiary compression to Quaternary extension in southern Tibet during the India-Asia collision. Tectonics, 6, 275-304.

Mériaux, A. S., Tapponnier, P., Ryerson, F. J., Xu, X., King, G., Van der Woerd, J., et al. (2005), The Aksay segment of the northern Altyn Tagh fault: Tectonic geomorphology, landscape 
evolution, and Holocene slip rate. Journal of Geophysical Research, 110, B04404, doi:10.1029/2004JB003210.

Molnar, P., \& Tapponnier, P. (1978), Active tectonics of Tibet. Journal of Geophysical Research, $83,5361-5375$.

Molnar, P., \& Chen, W. P. (1983), Focal Depths and Fault Plane Solutions of Earthquakes under the Tibetan Plateau. Journal of Geophysical Research, 88, 1180-1196.

Molnar, P., \& Lyon-Caen, H. (1989), Fault plane solutions of earthquakes and active tectonics of the Tibetan Plateau and its margins. Geophysical Journal International, 99, 123 - 153.

Murphy, M.A., Taylor, M.H., Gosse, J., Silver, C.R.P., Whipp, D.M., \& Beaumont, C. (2014), Limit of strain partitioning in the Himalaya marked by large earthquakes in western Nepal. Nature Geoscience, 7, 38-42.

Ni, J., \& York, J. E. (1978), Late Cenozoic tectonics of the Tibetan Plateau. Journal of Geophysical Research, 83, 5377-5384.

Owen, L. A., Finkel, R. C., Barnard, P. L., Haizhou, M., Asahi, K., Caffee, M. W., \& Derbyshire, E. (2005), Climatic and topographic controls on the style and timing of Late Quaternary glaciation throughout Tibet and the Himalaya defined by ${ }^{10} \mathrm{Be}$ cosmogenic radionuclide surface exposure dating. Quaternary Science Reviews, 24, 1391-1411.

Owens, T.J., \& Zandt, G. (1997), Implications of crustal property variations for models of Tibetan plateau evolution: Nature, v. 387, p. 37-43.

Pan, J., Li, H., Sun, Z., Liu, D., Lu, H., Zheng, Y., \& Chevalier, M.L. (2018), Reassessment of the late Quaternary slip rate of the Shuanghu graben, central Tibet, AGU Fall Meeting.

Patriat, P., \& Achache, J. (1984), India-Eurasia collision chronology has implications for crustal shortening and driving mechanism of plates. Nature. 311, 615-621. doi:10.1038/311615a0. 
Peltzer, G., \& Tapponnier, P. (1988), Formation and evolution of strike-slip faults, rifts, and basins during the India-Asia collision: An experimental approach. Journal of Geophysical Research, 93, 15085-15117.

Peltzer, G., \& Saucier, F. (1996), Present-day kinematics of Asia derived from geologic fault rates. Journal of Geophysical Research, 101, 27,943-27,956.

Ratschbacher, L., Krumrei, I., Blumenwitz, M., Staiger, M., Gloaguen, R., Miller, B. V., et al. (2011), Rifting and strike-slip shear in central Tibet and the geometry, age and kinematics of upper crustal extension in Tibet. Geological Society of London Special Publication, 353(1), $127-163$.

Replumaz, A. \& Tapponnier, P. (2003), Reconstruction of the deformed collision zone between India and Asia by backward motion of lithospheric blocks. Journal of Geophysical Research, 108. doi:10.1029/2001jb000661.

Robinson, A.C. (2009), Geologic offsets across the northern Karakorum fault: implications for its role and terrane correlations in the western Himalayan-Tibetan orogen. Earth and Planetary Science Letters, 279, 123-130. doi:10.1016/j.eps1.2008.12.039.

Roger, F., Tapponnier, P., Arnaud, N., Scharer, U., Brunel, M., Xu., Z., Yang, J. (2000), An Eocene magmatic belt across central Tibet: mantle subduction triggered by the Indian collision? Terra Nova, 12, 102-108.

Rowley, D.B. \& Currie B.S. (2006), Palaeo-altimetry of the late Eocene to Miocene Lunpola basin, central Tibet. Nature 439:677-81.

Ryder, I., Wang, H., Bie, L., \& Rietbrock, A. (2014), Geodetic imaging of late postseismic lower crustal flow in Tibet. Earth and Planetary Science Letters, 404, 136-143.

Sanchez, V. I., Murphy, M. A., Dupre, M.R., Ding, L., \& Zhang, R. (2010), Structural evolution of the Neogene Gar Basin, western Tibet: Implications for releasing bend development and 
drainage patterns. Geological Society of America Bulletin, 122, 5/6, 926-945, doi:10.1130/B26566.1.

Spicer, R.A., Harris, N.B.W., Widdowson, M., Herman, A.B., Guo, S., et al. (2003), Constant elevation of southern Tibet over the past 15 million years. Nature, 421:622-24

Stone, J.O. (2000), Air pressure and cosmogenic isotope production. Journal of Geophysical Research, 105, 23,753-23,759.

Styron, R., Taylor, M., \& Murphy, M. A. (2011), Oblique convergence, arc-parallel extension, and the role of strike-slip faulting in the High Himalaya. Geosphere 7, 582-596.

Styron, R., M. Taylor, K.E. Sundell, D. F. Stockli, J. A. G. Oalmann, A.Mšller, A. T. McCallister, D. Liu, \& L. Ding (2013), Miocene initiation and acceleration of extension in the South Lunggar rift, western Tibet: Evolution of an active detachment system from structural mapping and (U-Th)/He thermochronology, Tectonics, 32, 1-28, doi:10.1002/tect.20053.

Styron, R.H., Taylor, M., \& Sundell, K. (2015), Accelerated extension of Tibet linked to the northward underthrusting of Indian crust. Nature Geoscience, 8, 131-134. doi:10.1038/NGEO2336.

Sundell, K. E., Taylor, M. H., Styron, R. H., Stockli, D. F., Kapp, P., Hager, C., Liu, D., \& Ding, L. (2013), Evidence for constriction and Pliocene acceleration of east-west extension in the North Lunggar rift region of west central Tibet. Tectonics 32:1454-1479.

Tapponnier, P., Mercier, J. L., Armijo, R., Han, T., \& Zhao, T. J. (1981), Field evidence for active normal faulting in Tibet. Nature, 294, $410-414$.

Tapponnier P., Peltzer, G., \& Armijo, R. (1986), On the mechanics of the collision between India and Asia, Collision Tectonics, edited by J.G. Ramsay, M.P. Coward, and A. Ries. Special Publication of the Geological Society of London, 19, 115-157.

Tapponnier, P., Xu, Z., Roger, F., Meyer, B., Arnaud, N., Wittlinger, G., \& Yang, J. (2001), 
Taylor, M., Yin, A., Ryerson, F. J., Kapp, P., \& Ding, L. (2003), Conjugate strike-slip faulting along the Bangong-Nujiang suture zone accommodates coeval east-west extension and north-south shortening in the interior of the Tibetan Plateau. Tectonics, 22(4), 1044, doi:10.1029/2002TC001361.

Taylor, M., \& Peltzer, G. (2006), Current slip rates on conjugate strike-slip faults in central Tibet using synthetic aperture radar interferometry. Journal of Geophysical Research, 111(B12402). doi:10.1029/2005JB004014.

Tian, Z., Yang, Z., Bendick, R., Zhao, J., Wang, S., Wu, X., \& Shi, Y. (2019), Present-day distribution of deformation around the southern Tibetan Plateau revealed by geodetic and seismic observations. Journal of Asian Earth Sciences, 171, 321-333, doi:10.1016/j.jseaes.2018.12.018.

Tilmann, F., Ni, J., \& Team, I.I.S., (2003), Seismic imaging of the downwelling Indian lithosphere beneath central Tibet. Science, 300, 1424-1427.

Valli, F., Arnaud, N., Leloup, P. H., Sobel, E. R., Mahéo, G., Lacassin, R., et al. (2007), Twenty million years of continuous deformation along the Karakorum fault, western Tibet: a thermochronological analysis. Tectonics, 26(TC4004). doi:10.1029/2005TC001913.

Van Der Woerd, J., Tapponnier, P., Ryerson, F. J., Meriaux, A.S., Meyer, B., Gaudemer, Y., et al. (2002), Uniform postglacial slip-rate along the central $600 \mathrm{~km}$ of the Kunlun fault (Tibet), from ${ }^{26} \mathrm{Al},{ }^{10} \mathrm{Be}$, and ${ }^{14} \mathrm{C}$ dating of riser offsets, and climatic origin of the regional morphology. Geophysical Journal International, 148(3), 356-388.

Vergne, J., Wittlinger, G., Hui, Q.A., Tapponnier, P., Poupinet, G., Mei, J., Herquel, G., \& A. Paul (2002), Seismic evidence for stepwise thickening of the crust across the NE Tibetan plateau, Earth and Planetary Science Lettres, 203, 25-33, doi:10.1016/S0012-821X(02)00853-1. 
1034 Wang, Q., Zhang, P. Z., Freymueller, J. T., Bilham, R., Larson, K. M., Lai, X., et al. (2001), 1035 Present-day crustal deformation in China constrained by global positioning system measurements. Science, 294, $574-577$.

1037

1038

1039

1040

1041

1042

1043

1044

1045

1046

1047

1048

1049

1050

1051

1052

1053

1054

1055

1056

1057

Wang, H., Elliott, J. R., Craig, T. J., Wright, T. J., Liu-Zeng, J., \& Hooper, A. (2014), Normal faulting sequence in the Pumqu-Xainza Rift constrained by InSAR and teleseismic bodywave seismology. Geochemistry Geophysics Geosystems, 15, doi:10.1002/2014GC005369.

Wang, C., Dai, J., Zhao, X., Li, Y., Graham, S. A., He, D., et al. (2014), Outward-growth of the Tibetan Plateau during the Cenozoic: A review. Tectonophysics, 621, 1-43.

Wang, W., Qiao, X., Yang, S., \& Wang, D. (2017), Present day velocity field and block kinematics of Tibetan Plateau from GPS measurements. Geophysical Journal International, 208, 10881102. doi:10.1093/gji/ggw445.

Wang, H., Wright, T. J., Liu-Zeng, J., \& Peng, L. (2019), Strain rate distribution in south-central Tibet from two decades of InSAR and GPS. Geophysical Research Letters, 46. doi:10.1029/2019GL081916.

Wang, S., Chevalier, M.-L., Pan, J., Bai, M., Li, H., Li, K., \& Liu, F. (2020), Late Quaternary activity of the southern Yadong-Gulu rift, southern Tibet. in revision in Tectonophysics.

Wang, Y., Wang, P., Ge, W., Zhou, R., Schoenbohm, L. M., Zhang, B., et al. (2019), Differential crustal deformation across the Cona-Oiga rift, southern Tibetan Plateau. Journal of Asian Earth Sciences, 177, 177-185. doi:10.1016/j.jseaes.2019.03.023.

Wernicke, B. (1985), Uniform-sense normal simple shear of the continental lithosphere. Canadian Journal of Earth Sciences, 22, 108-125.

Wittlinger, G., J. Vergne, P. Tapponnier, V. Farra, G. Poupinet, M. Jiang, H. Su, G. Herquel, \& A. Paul (2004), Teleseismic imaging of subducting lithosphere and Moho offsets beneath western Tibet, Earth and Planetary Science Letters, 221(1-4), 117- 130. 
1058 Wolff, R., Hetzel, R., Dunkl, I., Xu, Q., Bröcker, M., \& Anczkiewicz, A.A. (2019), High-Angle Normal Faulting at the Tangra Yumco Graben (Southern Tibet) since $\sim 15$ Ma. The Journal of Geology, 127. doi:10.1086/700406.

1061

1062

1063

1064

1065

1066

1067

1068

1069

1070

1071

1072

1073

1074

1075

1076

1077

1078

1079

1080

1081

Wu, Z. M, Cao, Z. Q., Shentu, B. M., \& Deng, Q. D. (1992), Active Fault in the Central Tibet. Seismological Press, Beijing. pp. 161-192. (in Chinese with English abstract).

Wu, Z., Zhao, X., Wu, Z., Jiang, W., Hu, D., \& Zhou, C. (2004), Quaternary geology and faulting in the Damxung-Yangbajain basin. Acta Geologica Sinica, 78, 1, 273-282.

Wu, Z., Ye, P., Barosh, P., \& Wu, Z. (2011), The October 6, 2008 Mw 6.3 magnitude Damxung earthquake, Yadong-Gulu rift,Tibet, and implications for present-day crustal deformation. Journal of Asian Earth Sciences, 40, 943-957. doi:10.1016/j.jseaes.2010.05.003.

Wu, Z., Ye, P., Wang, C., Zhang, K., Zhao, H., Zheng, Y., et al. (2015), The Relics, Ages and Significance of Prehistoric Large Earthquakes in the Angang Graben in South Tibet. Earth Science - Journal of China University of Geosciences, 40 (10). doi:10.3799/dqkx.2015.147. (in Chinese with English abstract).

Wu, C., Tian, X., Xu, T., Liang, X., Chen, Y., Zhu, G., et al. (2019), Upper-Crustal Anisotropy of the Conjugate Strike-Slip Fault Zone in Central Tibet Analyzed Using Local Earthquakes and Shear-Wave Splitting. Bulletin of the Seismological Society of America. doi: $10.1785 / 0120180333$.

Yin, A., Kapp, P. A., Murphy, M. A., Harrison, T. M., Grove, M., Ding, L., et al. (1999), Significant late Neogene east-west extension in northern Tibet. Geology, 27, 787 - 790.

Yin, A. (2000), Mode of Cenozoic east-west extension in Tibet suggests a common origin of rifts in Asia during the Indo-Asian collision. Journal of Geophysical Research, 105, 21,74521,759 .

Yin, A., \& Taylor, M. H., (2011), Mechanics of V-shaped conjugate strike-slip faults and the 
corresponding continuum mode of continental deformation. Geological Society of America Bulletin, 123, 9/10, 1798-1821. doi:10.1130/B30159.1.

Zechar, J.D., \& Frankel, K. L. (2009), Incorporating and reporting uncertainties in fault slip rates. Journal of Geophysical Research, 114(B12407). Doi:10.1029/2009JB006325.

Zhang, P. Z., Shen, Z., Wang, M., Gan, W. J., Burgmann, R., \& Molnar, P. (2004), Continuous deformation of the Tibetan Plateau from global positioning system data. Geology, 32, 809812.

Zheng, G., Wang, H.,Wright, T. J., Lou, Y., Zhang, R., Zhang,W., et al. (2017), Crustal deformation in the India-Eurasia collision zone from 25-years of GPS measurements. Journal of Geophysical Research, 122, 9290-9312. doi:10.1002/2017JB014465.

Zhu, G. H., X. F. Liang, X. B. Tian, H. F. Yang, C. L.Wu, Y. H. Duan, et al. (2017), Analysis of the seismicity in central Tibet based on the SANDWICH network and its tectonic implications. Tectonophysics, 702, 1-7, doi: 10.1016/j.tecto.2017.02.020.

\section{Figure captions}

Figure 1: Southern Tibet normal faults and Yadong-Gulu rift in the frame of the India - Asia collision zone (modified from Tapponnier et al., 2001). (a) Tectonic map of southern Tibet with digital elevation model (DEM) in the background (location shown in inset), with active faults, main cities/towns and lakes, historical and recorded earthquakes of $M>6$ (from the U.S. Geological Survey), and horizontal GPS velocities relative to stable Eurasia (Zheng et al., 2017). The most prominent rift, that of Yadong-Gulu (YGR) is located in the far right (box b). The other main rifts are $C O R=$ Cona-Oiga rift, $P X R=$ Pumqu-Xainza rift, $A D R=$ Ama Drime rift (or Dinggye), TYR = Tangra Yum Co rift, KCR = Kung Co rift, LKR = Lopu Kangri rift, TKG= Thakkhola rift, LGR= Lunggar rift, GMR = Gurla Mandhata rift (or Pulan). RPCF = Riganpei Co fault, WNFS = Western Nepal fault system, GCF = Gyaring Co fault, BCF = Beng Co fault, BNS = BangongNujiang suture, $Y Z S=$ Yarlung Zangbo suture, $S F=$ Sagaing fault, $R R F=$ Red River fault, $K J F Z=$ Karakorum-Jiali fault zone. (b) Close-up of the northern half of the YGR, from the YZS to the Beng 
1109 Co fault, with main cities, earthquakes (from the U.S. Geological Survey) and focal mechanisms of 1110 instrumental earthquakes of Mw>5 (CMT catalogue 1976-2016), and study sites (blue stars). The 11111411 M8.0? historical earthquake is from Wu et al. (1992). Location of Figures 2 and 3 is

1112 indicated. (c) Topographic profiles at various locations perpendicular to the rift, with traces of 1113 main active faults.

1114

1115 Figure 2: Google Earth image of the northernmost Yadong-Gulu rift. (a) The Gulu half-graben and 1116 Damxung corridor along the Nyainqentanghla Range. Note the left-lateral component of motion on 1117 NE to EW-striking faults (black arrows). Yellow polygons represent sites discussed in Armijo et al. 1118 (1986) and green stars refer to the sites studied here $(T=$ terrace, $M=$ moraine $)$ with associated 1119 figure numbers. (b-e) Close-up of areas (locations in a) showing clear left-lateral motion, where 1120 horizontal offsets of rivers, moraine edges, and other morphologic markers, are highlighted by 1121 white/black dashed lines and approximate offset values are indicated. Colored triangles show fault 1122 traces. Damxung T site is presented in more details in Figures 11-13. PA = pull-apart.

1124 Figure 3: Google Earth image of the central Yadong-Gulu rift: the Damxung corridor, Yangbajing and Angang grabens. Yellow polygons represent sites discussed in Armijo et al. (1986) and green stars refer to the sites studied here ( $T=$ terrace, $M=$ moraine) with associated figure numbers. Note the $\sim 4 \mathrm{~km}$ horizontal offset of the western edge of the Yangbajing graben and

1128 Nyainqentanghla Range, as described in Armijo et al. (1986). Dong et al. (2017)'s study is located $11295 \mathrm{~km}$ west of the map.

Figure 4: The Gulu moraine site. (a) Bing satellite image of the Gulu moraine site and (b) its interpretation. The $400 \mathrm{~m}$ wide normal fault zone here is made of numerous fault segments in red, dipping in opposite directions. Samples collected upstream (Gulu W) and downstream (Gulu E)

1134 from the fault are shown by white circles with corresponding sample numbers. Location of photos from Figure 5 is also indicated. (c) Bird's eye view toward the WNW, taken from a drone (Unmanned Aerial Vehicle) of the entire site with cars circled for scale. Black lines with white polygonal tips show the intersection between the shallow-dipping detachment fault and surface topography, while those with green polygonal tips show roughly parallel shallow-dipping triangular facets $\left(\sim 10-20^{\circ}\right)$ on the bedrock footwall farther upstream in the valley. See text for 1140 details. 
1142 Figure 5: Field photos of the Gulu moraine site. (a) Numerous normal fault scarps facing opposite

1143 directions (forming small depressions) transversally cut the Gulu moraine. (b) View from upstream,

1144 where the Gulu half-graben floor is visible, as well as the terraces (T) present along the river. Cars

1145 circled for scale. Faults highlighted by red arrows. Close-up in $\boldsymbol{f}$. (c,d) Fault scarps. (e) Numerous

1146 fault scarps highlighted by shadow and red arrows. Photo locations shown in Figure 4.

Figure 6: LiDAR Digital Elevation Model (DEM) of the Gulu moraine site (a) with profiles across the fault zone showing the total subsidence of the moraine at $40 \pm 4 \mathrm{~m}$ (b). (c) 1:1 profile with fault geometry at depth, with a measured $18^{\circ}$-dipping detachment fault (green) into which shallow faults root (red) (Wernicke, 1985). See text for details.

Figure 7: ${ }^{10}$ Be cosmogenic surface-exposure ages of the Gulu M and Ybj M sites (moraines), using the Lal (1991)/Stone (2000) time-dependent model with 1- $\sigma$ uncertainty. Oldest age (circled) of each moraine is shown with value displayed in the box, representing the minimum moraine abandonment age. Numbers next to samples refer to sample names in Table 1.

Figure 8: The Gulu terrace site. (a) Bing satellite image of the Gulu terrace site and (b) its interpretation. One main cumulative normal fault scarp cuts and vertically offsets the Gulu terrace/fan. Ruptures from the 1952 Gulu earthquake are visible in the footwall. Samples collected upstream (Tup) and downstream (Tdown) from the fault are shown by white circles with corresponding sample names. (c,d) Field photos of the main cumulative fault scarp. (e) View from Tup with people circled for scale. Note the rockfall on Tup, forcing us to sample near the terrace riser above the river to avoid possible contamination. $(\boldsymbol{f})$ Bird's eye view of the entire site taken from a drone. This photo was taken $>10$ years after photos in c-e, hence differences such as the larger extent of the village in the hanging wall as well as the presence of prayer flags where we sampled on Tup. Thin red lines show the surface ruptures from the 1952 earthquake.

Figure 9: LiDAR DEM of the Gulu terrace site (a) with profiles across the fault zone showing the total vertical offset, averaging at $25 \pm 2 m(\boldsymbol{b}, \boldsymbol{c})$.

1172 Figure 10: ${ }^{10}$ Be and ${ }^{26}$ Al cosmogenic surface-exposure ages of the Gulu T, Damxung T, and Gyekar 1173 T sites (terraces), using the Lal (1991)/Stone (2000) time-dependent model with 1- $\sigma$ uncertainty.

1174 Outliers in white are discarded (using Peirce criterion) when calculating the average age of the 
1175 surface (indicated under the site names and shown by grey boxes). Some outliers (marked with a *

1176 symbol) require specific discussion, see text for details. Numbers next to samples refer to sample

1177 names in Table 2. Note the zoom in ages at Damxung T1 and T2 with the change of scale. To the

1178 right, the global climatic proxy curve of Lisiecki and Raymo (2005) shows the Marine oxygen

1179 Isotope Stages (MIS) 1 to 11.

1180

1181 Figure 11: The Damxung terrace site. (a) Google Earth image of the Damxung terraces site and (b)

1182 its interpretation. Here, two parallel normal-sinistral faults F1 and F2 cut the terraces. Collected

1183 samples are shown by white circles with corresponding sample names on T1 (lower terrace) and T2

1184 (upper terrace). Location of Figure 11d and photos from Figure 12 are also indicated. (c) Cartoon

1185 modified from Armijo et al. (1986) showing how slip is partitioned between normal and left-lateral

1186 motion along both parallel faults at this site. (d) Horizontal offset by F2 of the western edge of T1

1187 (17 $\pm 5 \mathrm{~m})$, as measured by back-slipping the LiDAR DEM and the contour lines. Location of $\boldsymbol{d}$

1188 shown in $\boldsymbol{b}$.

1189

1190 Figure 12: Field photos of the Damxung terrace site. (a) View from T2 (upper terrace) looking at

$1191 T 1$ (lower terrace) and the two parallel faults F1 and F2. (b) View of F2 and its fault scarp on T1

1192 (highlighted by red arrows), along which two large pull-aparts developed. (c,d) Pull-apart on T1

1193 along F2. Cars and people circled for scale. Photo locations shown in Figure 11.

1195 Figure 13: LiDAR DEM of the Damxung terrace site (a). (b) Profiles P6 and P7 across the faults

1196 (note the two different scales) showing the total vertical offset of T2, averaging at 184 $3 \mathrm{~m}$. (c)

1197 Profiles P3-P5 and (d) P1-P2 across T1, averaging at 10 $2 \mathrm{~m}$. Faults F1 and F2 highlighted by red

1198 arrows in $\boldsymbol{a}$.

1199

1200 Figure 14: The Yangbajing moraine site. (a) Bing satellite image of the Yangbajing moraine site

1201 and (b) its interpretation. One main fault cuts and vertically offsets the moraine crest. Samples

1202 collected upstream (Ybj W and N) and downstream (Ybj E) from the fault are shown by white

1203 circles with corresponding sample names. (c-e) Field photos showing the fault scarp and offset

1204 moraine crest (forming triangular facets). (f) View from upstream of the moraine crest and its large

1205 granite boulders. (g) View looking south, where the fault scarp and rupture is visible for $\sim 10 \mathrm{~km}$,

1206 possibly a relict of the nearby 1411 M8 (?) earthquake. 
1208 Figure 15: LiDAR DEM of the Yangbajing moraine site (a) with profiles across the fault showing the total vertical offset of $44 \pm 1 \mathrm{~m}(\boldsymbol{b})$. Faults $F 1$ and F2 highlighted by red arrows in $\boldsymbol{a}$.

1210

Figure 16: The Gyekar terraces site. (a) Google Earth image of the Gyekar terraces site and (b) its interpretation. Numerous parallel faults cut and vertically offset the fans/terraces. Faults in black may not be active at present. Collected samples from $T 1$ and T2 are shown by white circles with corresponding sample names. Location of photos from Figure 17 is indicated. (c) LiDAR DEM with contour lines (location in b).

Figure 17: Field photos of Gyekar terraces site. $(\boldsymbol{a}, \boldsymbol{b})$ Panoramic views of the flight of terraces with fault trace at mid-slope on the scarps. (c,i) Hot springs from the western side of the southern Yangbajing graben located across from the Gyekar terraces (location in Figure 3). (d,e) Photos showing the difference between the fault scarp at the base of T2, which is more diffused, covered with short grass, and with deeply entrenched gullies (d), and that at the base of T1, which is steeper, covered by less vegetation, and shallower gullies (e). Red arrows show fault trace. (f,g) Fault planes clearly exposed in gullies across T1/T0 and T2/T1 scarps, on which we precisely measured the fault dips. (h) Photo of the strath terrace below T2 and T3. Photo locations shown in Figure 16.

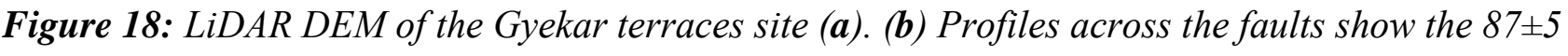
$m$ vertical offset across the T2/T1 scarp and that of $15 \pm 3 \mathrm{~m}$ across the T1/T0 scarp. Note the scale differences between the three sets of profiles. Faults F1 and F2 highlighted by red arrows in $\boldsymbol{a}$.

Figure 19: Summary of throw/extension rates along the Yadong-Gulu rift (YGR). See Table 3 for references to numbers. (a) Throw - vertical (black) / Extension - horizontal (green) rates at various timescales. (b) Extension rates along strike, rather constant south of the Gulu bend at $1.3 \pm 0.3$ $\mathrm{mm} / \mathrm{yr}$, and rapidly increasing north of it, most likely do to the transfer of slip from the dextral Beng Co fault.

Figure 20: Slopes map (from Fielding et al., 1994) highlighting different topographic and 
1239 correspond to distinct normal faulting areas north and south of the Bangong-Nujiang suture (BNS).

1240 Oblique white dashed line is the "chord" joining Nanga Parbat (NP) and Namche Barwa (NB) at 1241 both Himalayan syntaxes (after Armijo et al., 1986).

1242

1243 Table 1: ${ }^{10} \mathrm{Be}$ surface-exposure dating of the moraine samples.

1244

1245 Table 2: ${ }^{10} \mathrm{Be}$ and $26 \mathrm{Al}$ surface-exposure dating of the alluvial samples.

1247 Table 3 : Rates summary along the Yadong-Gulu rift. 
Sheet 1

Table 1: ${ }^{10} \mathrm{Be}$ surface-exposure dating of the moraine samples.

\begin{tabular}{|c|c|c|c|c|c|c|c|c|c|}
\hline & Sample name & Lat $\left({ }^{\circ} \mathrm{N}\right)$ & Long $\left({ }^{\circ} \mathrm{E}\right)$ & Elev. & Shielding & $10 \mathrm{Be}(\mathrm{at} / \mathrm{g})$ & err & Published age $\dagger$ & Recalculated age $\dagger$ \\
\hline \multirow[t]{7}{*}{ Gulu W } & T5C-58 & 30.81139 & 91.55621 & 5003 & 0.9916 & 1227679 & 24480 & $15486 \pm 1346$ & $16982 \pm 1618$ \\
\hline & T5C-59 & 30.81126 & 91.55642 & 5003 & 0.9916 & 1252031 & 24832 & $15768 \pm 1371$ & $17292 \pm 1647$ \\
\hline & T5C-60 & 30.81102 & 91.55689 & 4995 & 0.9951 & 1297396 & 23586 & $16292 \pm 1410$ & $17870 \pm 1696$ \\
\hline & T5C-61 & 30.81096 & 91.55738 & 4988 & 0.9951 & 1210116 & 25074 & $15328 \pm 1335$ & $16809 \pm 1604$ \\
\hline & T5C-62 & 30.81083 & 91.55754 & 4991 & 0.9951 & 1298660 & 37725 & $16333 \pm 1462$ & $17916 \pm 1749$ \\
\hline & T5C-63 & 30.81083 & 91.55754 & 4991 & 0.9951 & 1358947 & 34231 & $17026 \pm 1504$ & $18689 \pm 1804$ \\
\hline & T5C-64 & 30.81062 & 91.55782 & 4987 & 0.9947 & 1393854 & 35889 & $17464 \pm 1546$ & $19176 \pm 1854$ \\
\hline \multirow[t]{8}{*}{ Gulu E } & T5C-66 & 30.80783 & 91.56484 & 4932 & 0.9971 & 1584591 & 40335 & $20590 \pm 1822$ & $22044 \pm 2132$ \\
\hline & T5C-67 & 30.80783 & 91.56484 & 4932 & 0.9971 & 1364351 & 34705 & $17910 \pm 1584$ & $19195 \pm 1855$ \\
\hline & T5C-68 & 30.80751 & 91.56579 & 4958 & 0.9971 & 1320837 & 35843 & $17499 \pm 1556$ & $18421 \pm 1788$ \\
\hline & Т5C-69 & 30.80732 & 91.56593 & 4916 & 0.9971 & 1294481 & 32762 & $17308 \pm 153$ & $18401 \pm 1777$ \\
\hline & T5C-70 & 30.80798 & 91.56578 & 4914 & 0.9971 & 1300262 & 40576 & $17233 \pm 1556$ & $18493 \pm 1818$ \\
\hline & T5C-71 & 30.80849 & 91.56405 & 4876 & 0.9962 & 1512634 & 47528 & $19717 \pm 1782$ & $21643 \pm 2131$ \\
\hline & T5C-72 & 30.80851 & 91.56379 & 4869 & 0.9962 & 1219567 & 30955 & $16203 \pm 1432$ & $17774 \pm 1716$ \\
\hline & T5C-73 & 30.8077 & 91.56486 & 4855 & 0.9962 & 1273776 & 31228 & $16960 \pm 1495$ & $18618 \pm 1794$ \\
\hline \multirow[t]{10}{*}{ Ybj W } & T5C-25 & 30.02181 & 90.24252 & 5276 & 0.9826 & 2881748 & 52627 & $31104 \pm 2703$ & $34012 \pm 3242$ \\
\hline & T5C-26 & 30.02171 & 90.24297 & 5258 & 0.9826 & 2344650 & 42993 & $26094 \pm 2265$ & $28509 \pm 2714$ \\
\hline & T5C-27** & 30.0214 & 90.24315 & 5248 & 0.9826 & 1912313 & 37191 & $21797 \pm 1896$ & $23827 \pm 2271$ \\
\hline & T5C-28 & 30.02133 & 90.24332 & 5227 & 0.9868 & 2711638 & 70371 & $29907 \pm 2657$ & $32714 \pm 3176$ \\
\hline & T5C-29 & 30.02113 & 90.24345 & 5221 & 0.99 & 3202175 & 74603 & $3466 \pm 3057$ & $37563 \pm 3625$ \\
\hline & T5C-30\# & 30.02091 & 90.24372 & 5206 & 0.99 & 4812903 & 103646 & $49757 \pm 4383$ & $56086 \pm 5415$ \\
\hline & T5C-31 & 30.02077 & 90.24406 & 5200 & 0.99 & 1587965 & 30984 & $18585 \pm 1615$ & $20405 \pm 1943$ \\
\hline & T5C-32 & 30.02077 & 90.24406 & 5200 & 0.99 & 1457076 & 26595 & $17165 \pm 1487$ & $18838 \pm 1789$ \\
\hline & T5C-33 & 30.02065 & 90.24432 & 5184 & 0.99 & 2289852 & 41982 & $26123 \pm 2268$ & $28540 \pm 2717$ \\
\hline & T5C-34 & 30.02053 & 90.24472 & 5177 & 0.99 & 2987774 & 53120 & $33168 \pm 2881$ & $36135 \pm 3443$ \\
\hline \multirow[t]{10}{*}{ Ybj E } & T5C-35 & 30.0185 & 90.24805 & 5034 & 0.99 & 1485256 & 26941 & $18698 \pm 1620$ & $20532 \pm 1950$ \\
\hline & T5C-36 & 30.01823 & 90.24807 & 5033 & 0.99 & 3903265 & 83862 & $43556 \pm 3830$ & $47998 \pm 4624$ \\
\hline & T5C-37 & 30.01804 & 90.24783 & 5066 & 0.9926 & 3624150 & 64791 & $40331 \pm 3510$ & $43889 \pm 4191$ \\
\hline & T5C-38 & 30.01801 & 90.24822 & 5026 & 0.9926 & 4350087 & 75134 & $48461 \pm 4220$ & $54501 \pm 5212$ \\
\hline & T5C-39 $\S$ & 30.01802 & 90.24849 & 5021 & 0.9926 & 3081077 & 54984 & $36056 \pm 3134$ & $38991 \pm 3718$ \\
\hline & $\mathrm{T} 5 \mathrm{C}-40 * *$ & 30.01801 & 90.24865 & 5014 & 0.9926 & 3504063 & 66012 & $39996 \pm 3489$ & $43459 \pm 4157$ \\
\hline & T5C-41 & 30.0181 & 90.24931 & 5010 & 0.9926 & 3719922 & 65182 & $42047 \pm 3658$ & $46053 \pm 4397$ \\
\hline & T5C-42 $\S$ & 30.01796 & 90.24933 & 4999 & 0.9926 & 4321103 & 80325 & $48748 \pm 4259$ & $54862 \pm 5260$ \\
\hline & T5C-43§ & 30.01784 & 90.24949 & 4991 & 0.99 & 2163193 & 31645 & $26808 \pm 2309$ & $29272 \pm 2768$ \\
\hline & T5C-44 & 30.01782 & 90.2495 & 4982 & 0.9868 & 4112110 & 108452 & $46921 \pm 4193$ & $52539 \pm 5132$ \\
\hline \multirow[t]{2}{*}{ Ybj N } & T5C-44bis & 30.02351 & 90.24524 & 5239 & 0.9868 & 2105096 & 113008 & $23740 \pm 2386$ & $26013 \pm 2805$ \\
\hline & T5C-45 & 30.02402 & 90.24464 & 5261 & 0.9868 & 1073159 & 32747 & $12597 \pm 1133$ & $13899 \pm 1362$ \\
\hline \multirow[t]{5}{*}{ Ybj inner } & T5C-19** & 30.02319 & 90.24192 & 5305 & 0.99 & 947690 & 26149 & $10874 \pm 967$ & $12028 \pm 1167$ \\
\hline & T5C-20 & 30.02313 & 90.24197 & 5302 & 0.99 & 1135106 & 23814 & $13044 \pm 1137$ & $14368 \pm 1371$ \\
\hline & T5C-21 & 30.02313 & 90.24197 & 5302 & 0.99 & 904934 & 18644 & $10401 \pm 905$ & $11492 \pm 1095$ \\
\hline & T5C-22* & 30.02308 & 90.24198 & 5295 & 0.99 & 1821423 & 32544 & $20316 \pm 1759$ & $22256 \pm 2114$ \\
\hline & T5C-23 & 30.02298 & 90.24185 & 5287 & 0.99 & 1248601 & 25589 & $14384 \pm 1252$ & $15786 \pm 1505$ \\
\hline
\end{tabular}

$\dagger$ Ages published in Chevalier et al. (2011).

† Ages recalculated with the CRONUS 2.3 calculator using the Lal (1991)/Stone (2000) time-dependent production rate model.

${ }^{10} \mathrm{Be}$ production rate is $4.1 \mathrm{at} / \mathrm{g} / \mathrm{a}$. All samples were processed at Stanford University's cosmogenic facility.

$\S$ The ${ }^{10} \mathrm{Be} /{ }^{9} \mathrm{Be}$ ratios were measured at the Lawrence Livermore National Laboratory: 07KNSTD with ${ }^{10} \mathrm{Be}$ isotope ratios=2.79x $1 \mathrm{e}-11$.

For all other samples, the ${ }^{10} \mathrm{Be} /{ }^{9} \mathrm{Be}$ ratios were measured at CEREGE: NIST SRM4325 (=NIST_27900), equivalent to 07KNSTD.

* Outlier rejected using Peirce's criterion (following Blomdin et al., 2016).

**Sample was quartzite, all others were granite.

No erosion rate was applied. Thickness is $4 \mathrm{~cm}$. Density is $2.7 \mathrm{~g} / \mathrm{cm} 3$ for granite and $2.65 \mathrm{~g} / \mathrm{cm} 3$ for quartzite. 
Table 2: ${ }^{10} \mathrm{Be}$ and ${ }^{26} \mathrm{Al}$ surface-exposure dating of the alluvial samples.

\begin{tabular}{|c|c|c|c|c|c|c|c|c|c|c|c|c|c|c|}
\hline & Sample name & Lat $\left({ }^{\circ} \mathrm{N}\right)$ & Long $\left({ }^{\circ} \mathrm{E}\right)$ & Elev. & Shielding & ${ }^{10} \mathrm{Be}(\mathrm{at} / \mathrm{g})$ & err & ${ }^{26} \mathrm{Al}(\mathrm{at} / \mathrm{g})$ & err & ${ }^{10} \mathrm{Be}$ age $(\mathrm{yrs}) \dagger$ & err & ${ }^{26} \mathrm{Al}$ age $(\mathrm{yrs}) \dagger$ & err & ${ }^{26} \mathrm{Al} /{ }^{10} \mathrm{Be}$ conc. \\
\hline \multirow[t]{3}{*}{ Gulu T up } & T5C-75 & 30.67214 & 91.52428 & 4651 & 1 & 182971 & 6962 & 985830 & 67901 & 3286 & 330 & 2708 & 313 & 5.38 \\
\hline & T5C-78 & 30.67229 & 91.52379 & 4645 & 1 & 928065 & 32828 & 5121162 & 186501 & 15318 & 1526 & 12915 & 1295 & 5.51 \\
\hline & T5C-82 & 30.67217 & 91.52429 & 4651 & 1 & 254688 & 12780 & 1156740 & 189886 & 4434 & 468 & 3152 & 595 & 4.54 \\
\hline \multirow[t]{2}{*}{ Gulu $\mathrm{T}$ down } & T5C-85 & 30.67107 & 91.52791 & 4593 & 1 & 3663368 & 133994 & 19139157 & 715710 & 55054 & 5564 & 43256 & 4418 & 5.22 \\
\hline & T5C-91 & 30.67091 & 91.52925 & 4580 & 1 & 24917297 & 588827 & 137802787 & 3098854 & 403083 & 42733 & 359743 & 41179 & 5.53 \\
\hline \multirow[t]{5}{*}{ Damxung T1 } & T5C-102 & 30.52696 & 91.09392 & 4396 & 0.995952 & 969086 & 33817 & 5867556 & 204247 & 17919 & 1783 & 16563 & 1654 & 6.05 \\
\hline & T5C-107 & 30.52551 & 91.09152 & 4393 & 0.995952 & 1033288 & 32425 & 6930002 & 230822 & 19050 & 1874 & 19360 & 1926 & 6.7 \\
\hline & T5C-109b & 30.52353 & 91.09292 & 4382 & 0.995952 & 952869 & 44289 & 6361787 & 190541 & 17755 & 1850 & 17960 & 1766 & 6.67 \\
\hline & T5C-110 & 30.52114 & 91.09366 & 4362 & 0.998147 & 1131165 & 34136 & 7373984 & 213983 & 20975 & 2056 & 20768 & 2039 & 6.51 \\
\hline & T5C-114 & 30.5209 & 91.09295 & 4370 & 0.998147 & 976630 & 35198 & 6203038 & 197268 & 18227 & 1822 & 17605 & 1741 & 6.35 \\
\hline \multirow[t]{4}{*}{ Damxung T2 } & T5C-92 & 30.53208 & 91.09345 & 4556 & 0.998722 & 241631 & 12548 & 1488708 & 67609 & 4427 & 471 & 4148 & 429 & 6.16 \\
\hline & T5C-93b & 30.53286 & 91.09393 & 4562 & 0.998722 & 971983 & 33116 & 2718304 & 681725 & 16656 & 1652 & 7121 & 1911 & 2.79 \\
\hline & T5C-97 & 30.53232 & 91.09521 & 4558 & 0.998722 & 15986946 & 583503 & 81966276 & 1226356 & 250186 & 26558 & 198780 & 20621 & 5.12 \\
\hline & T5C-101 & 30.53143 & 91.0972 & 4544 & 0.998722 & 20312794 & 738851 & 110748873 & 1720803 & 325189 & 35173 & 283536 & 30745 & 5.45 \\
\hline Gyekar T1 & T5C-6 & 29.87901 & 90.37154 & 4435 & 1 & 10680049 & 379397 & 60015261 & 2143509 & 177988 & 18485 & 154808 & 16616 & 5.61 \\
\hline \multirow[t]{4}{*}{ Gyekar T2 } & T5C-14 & 29.8542 & 90.37619 & 4541 & 1 & 17211893 & 395395 & 77981065 & 3037209 & 277099 & 28393 & 193360 & 21419 & 4.53 \\
\hline & T5C-17 & 29.85402 & 90.3761 & 4543 & 1 & 13825128 & 464127 & 16233863 & 879683 & 217521 & 22662 & 39118 & 4283 & 1.17 \\
\hline & $\mathrm{T} 5 \mathrm{C}-50$ & 29.86142 & 90.37923 & 4541 & 1 & 15711102 & 349727 & 79143796 & 2784025 & 251826 & 25592 & 196184 & 21460 & 5.03 \\
\hline & T5C-56 & 29.86166 & 9037934 & 4540 & 1 & 6175938 & 191963 & 4992451 & 407129 & 97734 & 9796 & 13552 & 1685 & 0.8 \\
\hline
\end{tabular}

$\dagger$ Ages from Kali (2010) recalculated with the CRONUS v2.3 calculator using the Lal (1991)/Stone (2000) time-dependent production rate model. ${ }^{10} \mathrm{Be}$ production rate is 4.1 at/g/a. Samples were processed at the Institut de Physique du Globe de Strasbourg, France and ratios were measured at CEREGE: NIST SRM4325 (=NIST_27900), equivalent to $07 \mathrm{KNSTD}$ with ${ }^{10} \mathrm{Be}$ isotope ratios $=2.79 \mathrm{x} 1 \mathrm{e}-11$; SMAL11 for $26 \mathrm{Al}$ isotope ratios $=7.401 \times 1 \mathrm{e}-12$.

No erosion rate was applied. Density is $2.65 \mathrm{~g} / \mathrm{cm} 3$ (all samples are quartzite cobbles). Thickness is $5 \mathrm{~cm}$. 
Table 3 : Rates summary along the Yadong-Gulu rift

\begin{tabular}{|c|c|c|c|c|c|c|}
\hline & \multirow[t]{2}{*}{ Fault $\operatorname{dip}\left({ }^{\circ}\right)$} & \multicolumn{2}{|c|}{ Rate $(\mathrm{mm} / \mathrm{yr})$} & \multirow{2}{*}{ Reference } & \multirow[t]{2}{*}{ Method } & \multirow{2}{*}{$\begin{array}{l}\text { Ref. } \\
\text { in Fig. } 16 \\
\end{array}$} \\
\hline & & Throw & Extension & & & \\
\hline \multicolumn{7}{|l|}{ Geodetic } \\
\hline \multirow[t]{4}{*}{ Yadong-Gulu rift } & & & $4.5 \pm 0.5$ & Wang et al., 2019 & InSAR and GPS data & 1 \\
\hline & & & $\sim 6$ & Chen et al., 2004a,b & GPS, block model & 2 \\
\hline & & & $5.2 \pm 0.4$ & Wang et al., 2017 & GPS, block model & 3 \\
\hline & & & $2.0 \pm 0.6$ & Gan et al., 2007 & GPS, dislocation model & 4 \\
\hline Northern half & & & $5.6 \pm 0.8$ & Tian et al., 2019 & GPS, microplate model & 5 \\
\hline Late Quaternary & & & & & & \\
\hline Gulu Moraine & $18 \pm 5$ & $1.8 \pm 0.3$ & $6.0 \pm 1.8$ & This study & ${ }^{10} \mathrm{Be}$ & GM \\
\hline Gulu Terrace & $60-70$ & $6.4(+1.7 /-1.1)$ & $3.1 \pm 0.6$ & This study & ${ }^{10} \mathrm{Be}$ & GuT \\
\hline Damxung Terrace & 70 & $0.5-0.75 \pm 0.2$ & $<1.6$ & This study & ${ }^{10} \mathrm{Be}+\operatorname{dip} 70^{\circ}$ (two faults) & DT \\
\hline Yangbajing Moraines & 41 & $0.8 \pm 0.1$ & $0.9 \pm 0.1$ & This study & ${ }^{10} \mathrm{Be}$ & YM \\
\hline Gyekar Terraces & $55-65$ & $0.6 \pm 0.2$ & $0.3 \pm 0.1$ & This study & ${ }^{10} \mathrm{Be}$ & GyT \\
\hline \multirow[t]{4}{*}{ Yangbajing graben } & & & $1.2 \pm 0.2$ & This study, YM + GyT & ${ }^{10} \mathrm{Be}$ & $\mathrm{YM}+\mathrm{GyT}$ \\
\hline & & $\sim 1.6$ & & Armijo et al., 1986 & $100 \mathrm{~m}$ since $60 \mathrm{ka}$ (inferred ages) & $6 a$ \\
\hline & & $1.4 \pm 0.6$ & $1.3 \pm 0.7 *$ & Wu et al., 2004 (Holocene) & OSL, ESR and U-series & $7 \mathrm{a}$ \\
\hline & & $1.1 \pm 0.3$ & $0.9 \pm 0.5^{*}$ & Wu et al., 2004 (Quaternary) & OSL, ESR and U-series & $7 b$ \\
\hline Angang graben & & $0.8-1.3$ & $0.9 \pm 0.4^{*}$ & Wu et al., 2015 & OSL and ${ }^{14} \mathrm{C}$ & 8 \\
\hline \multirow[t]{2}{*}{ Yadong rift } & & $0.7 \pm 0.1$ & $0.6 \pm 0.1^{\#}$ & Ha et al., 2019 & OSL & 9 \\
\hline & 50 & $0.9 \pm 0.3$ & $0.8 \pm 0.3$ & Wang et al., 2020 & ${ }^{10} \mathrm{Be}$ & 10 \\
\hline \multicolumn{7}{|l|}{ Geologic } \\
\hline Yadong-Gulu rift & $45-60$ & $1.9 \pm 0.6$ & $1.4 \pm 0.8$ & Armijo et al., 1986 & $3-5 \mathrm{~km}$ since $2.0 \pm 0.5 \mathrm{Ma}$ & $6 b$ \\
\hline
\end{tabular}

*We calculated an EW extension rate using a $45^{\circ}-60^{\circ}$ dip angle

\#We calculated an EW extension rate using a $50^{\circ}$ dip angle

OSL $=$ Optically Stimulated Luminescence

$\mathrm{ESR}=$ Electron Spin Resonance 
Figure 1. 

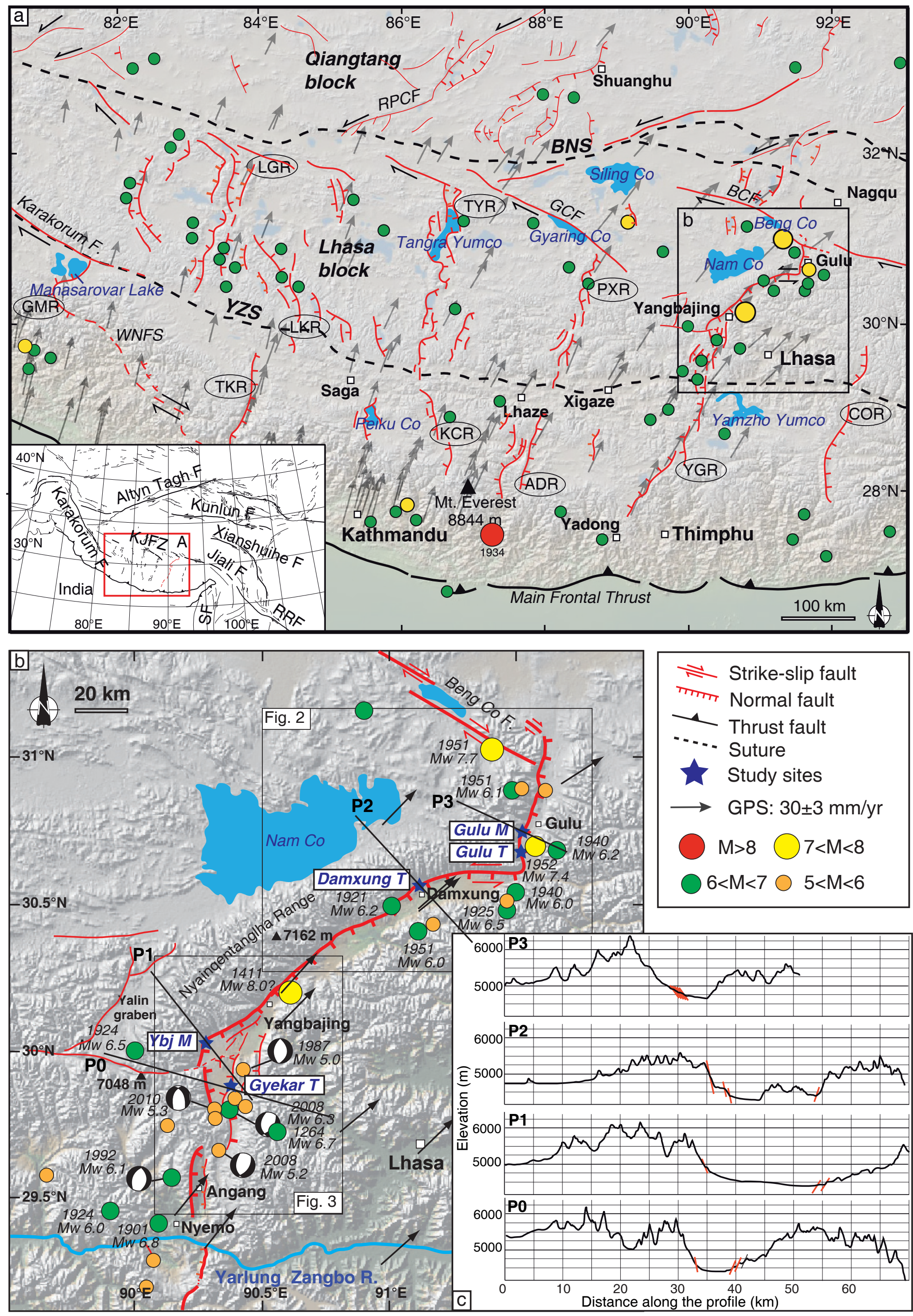
Figure 2. 
Figure 3. 


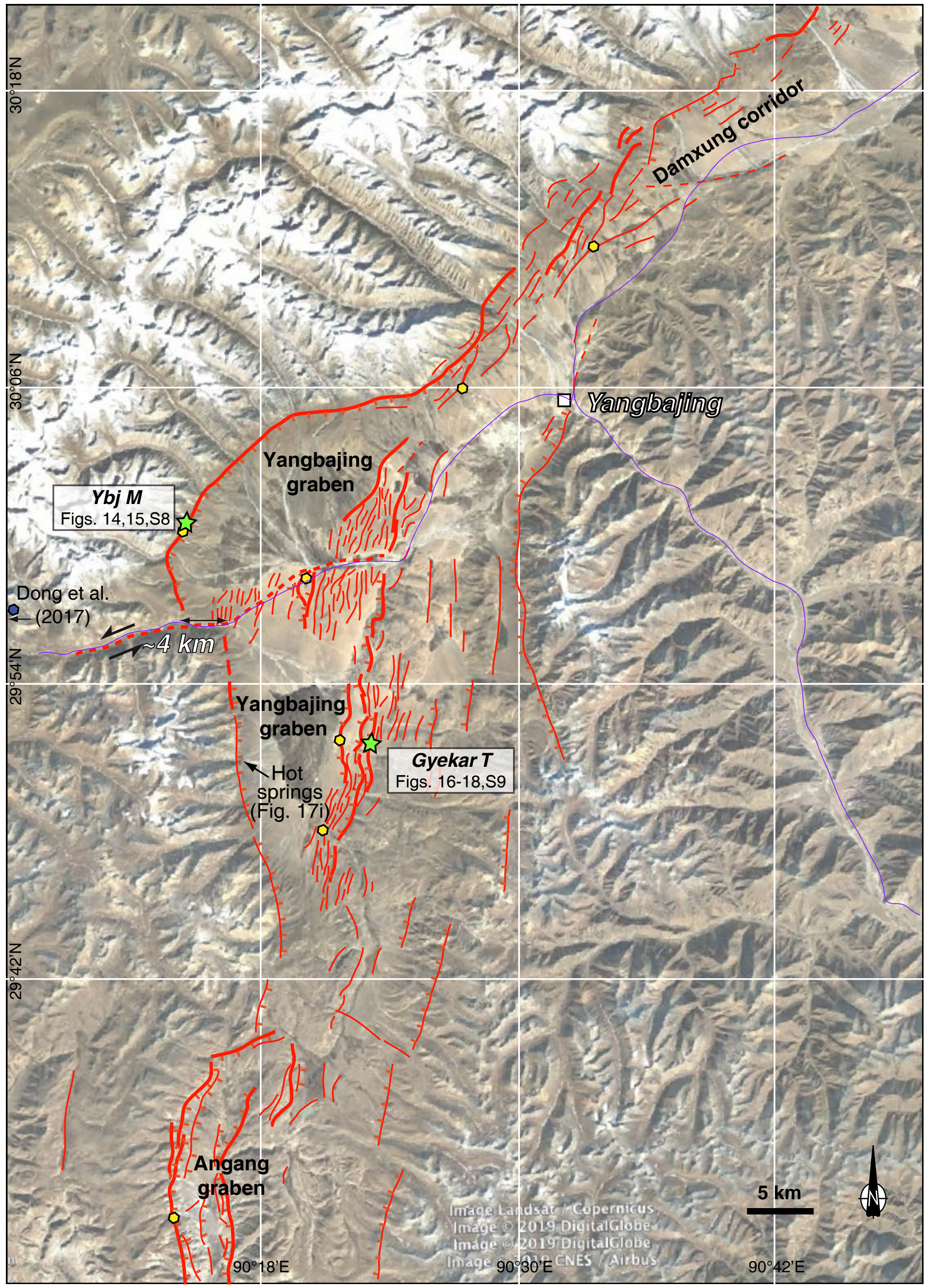


Figure 4. 
Figure 5. 


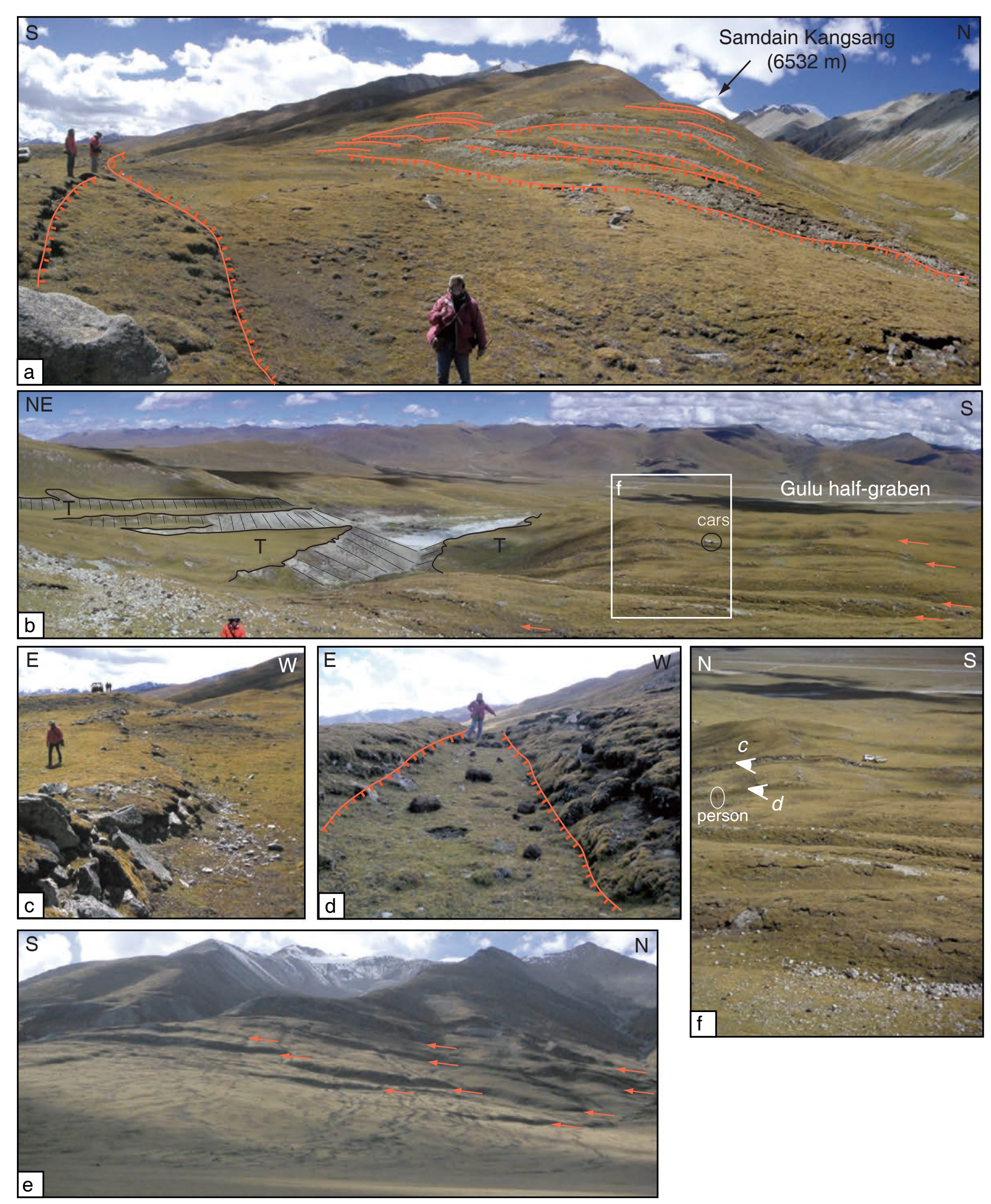


Figure 6. 

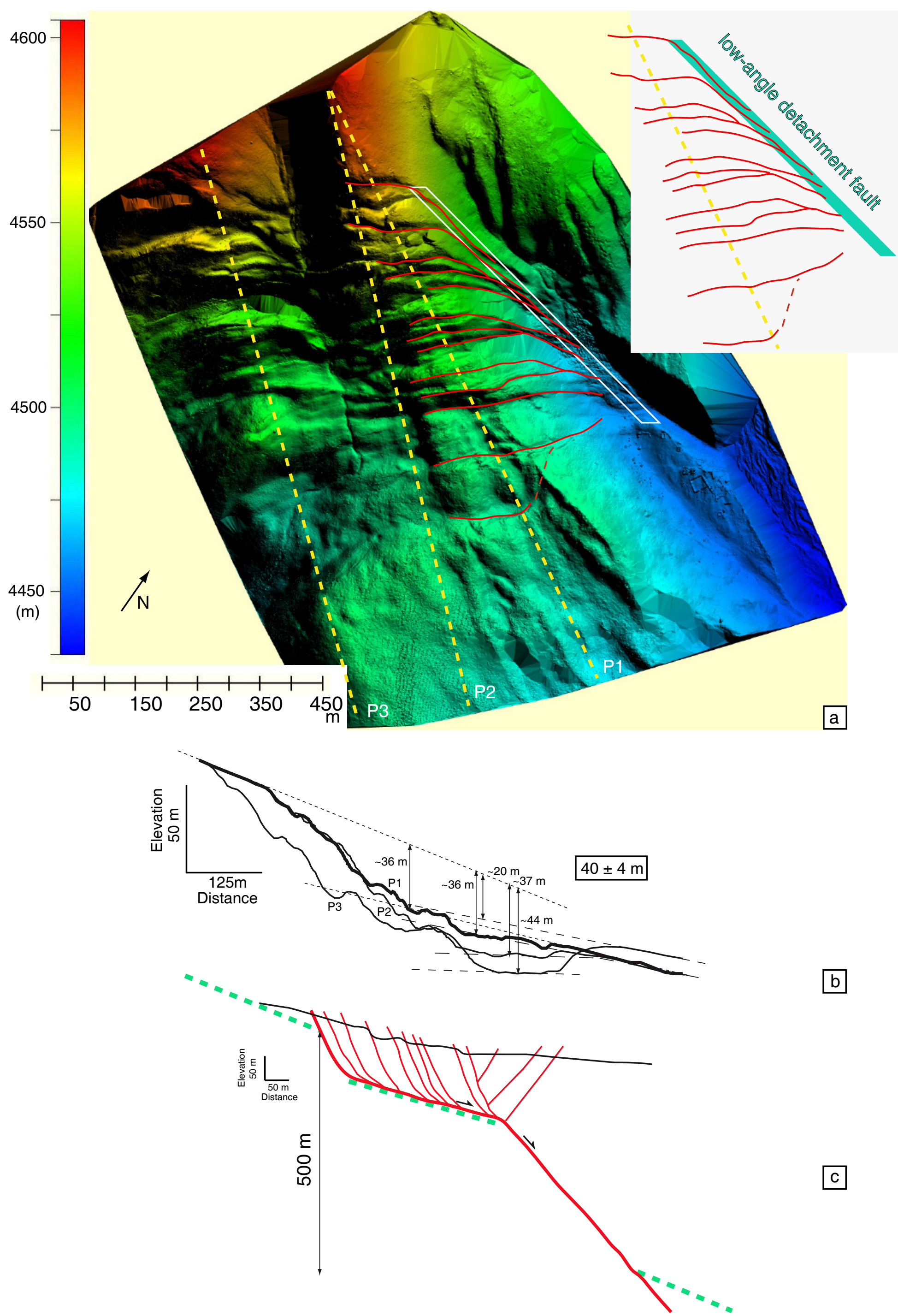
Figure 7. 


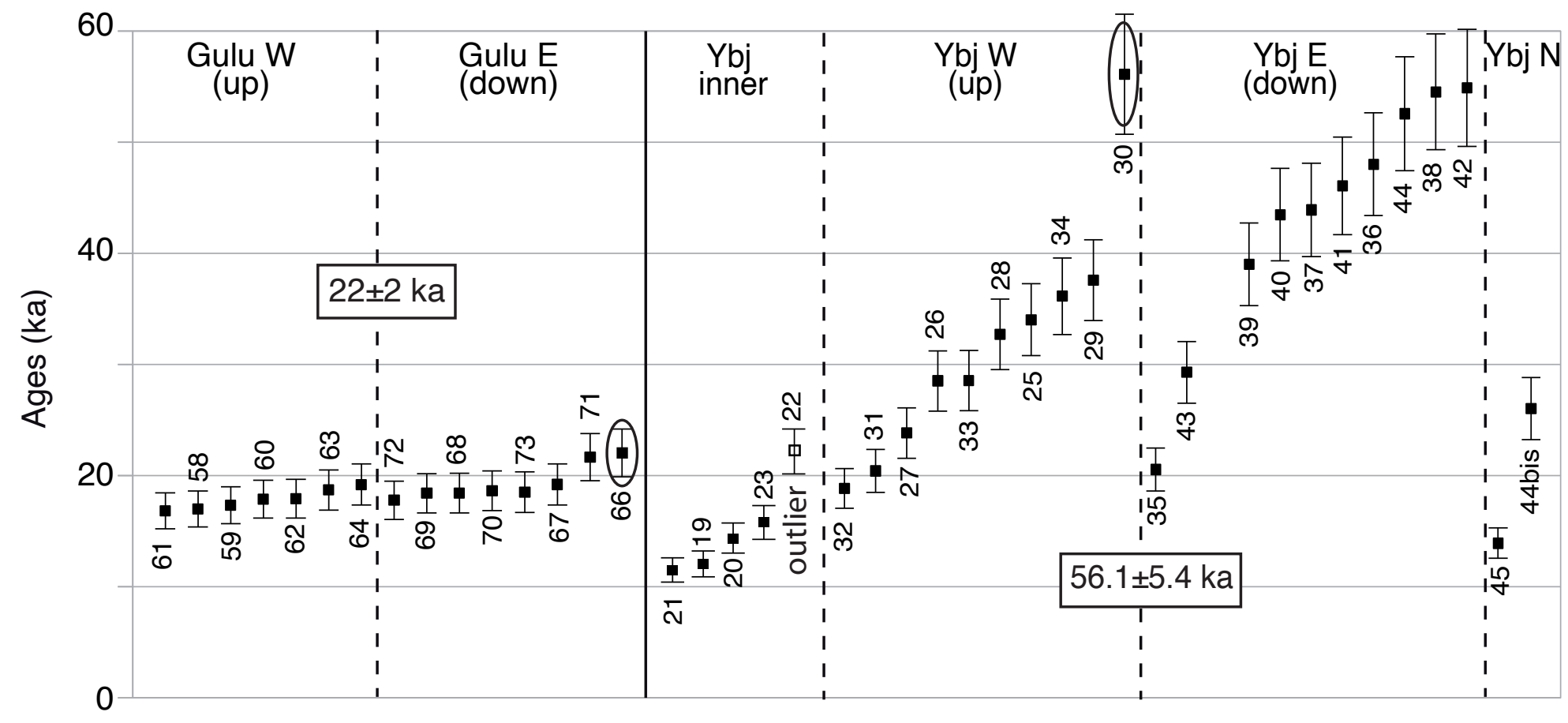


Figure 8. 

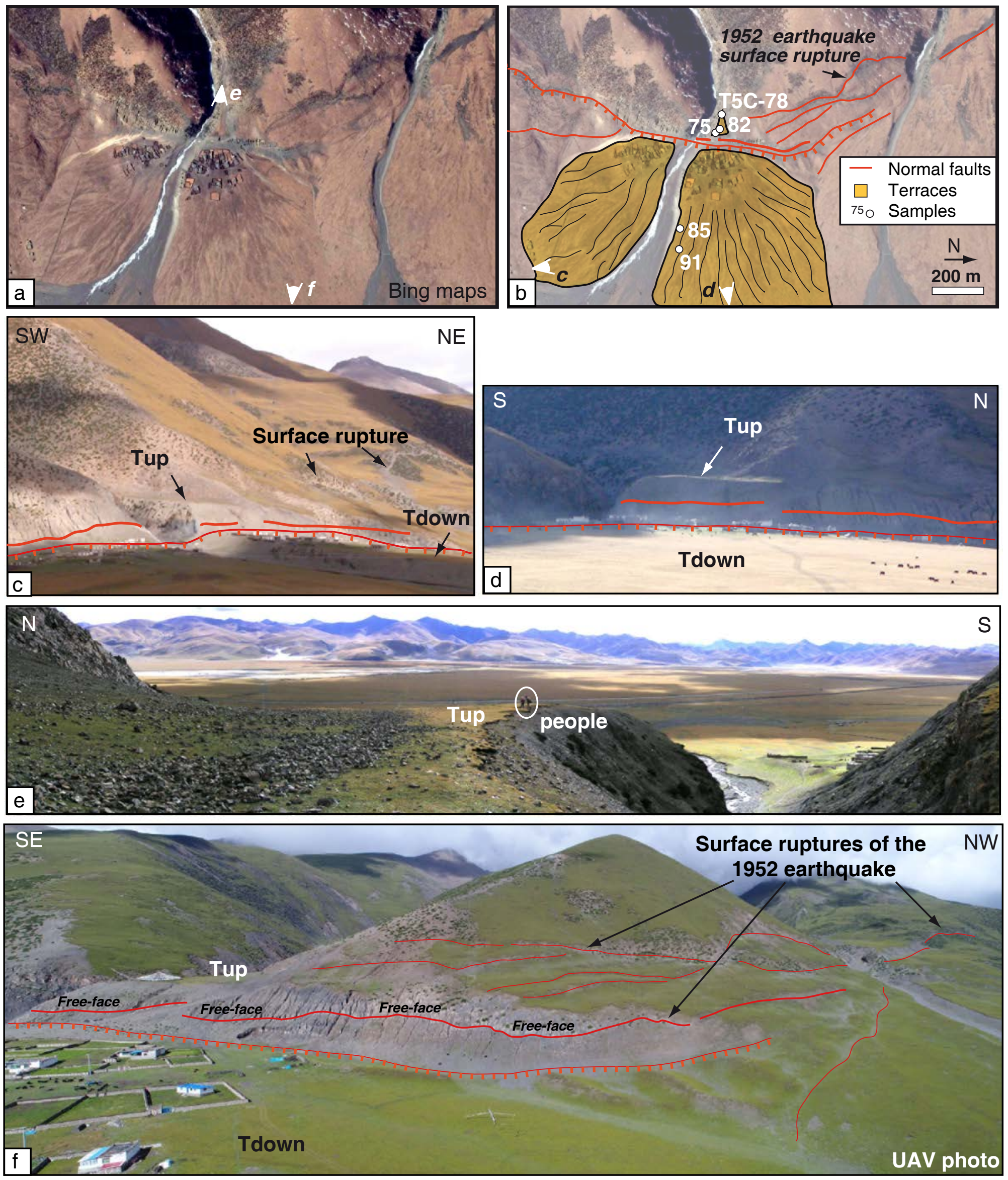
Figure 9. 

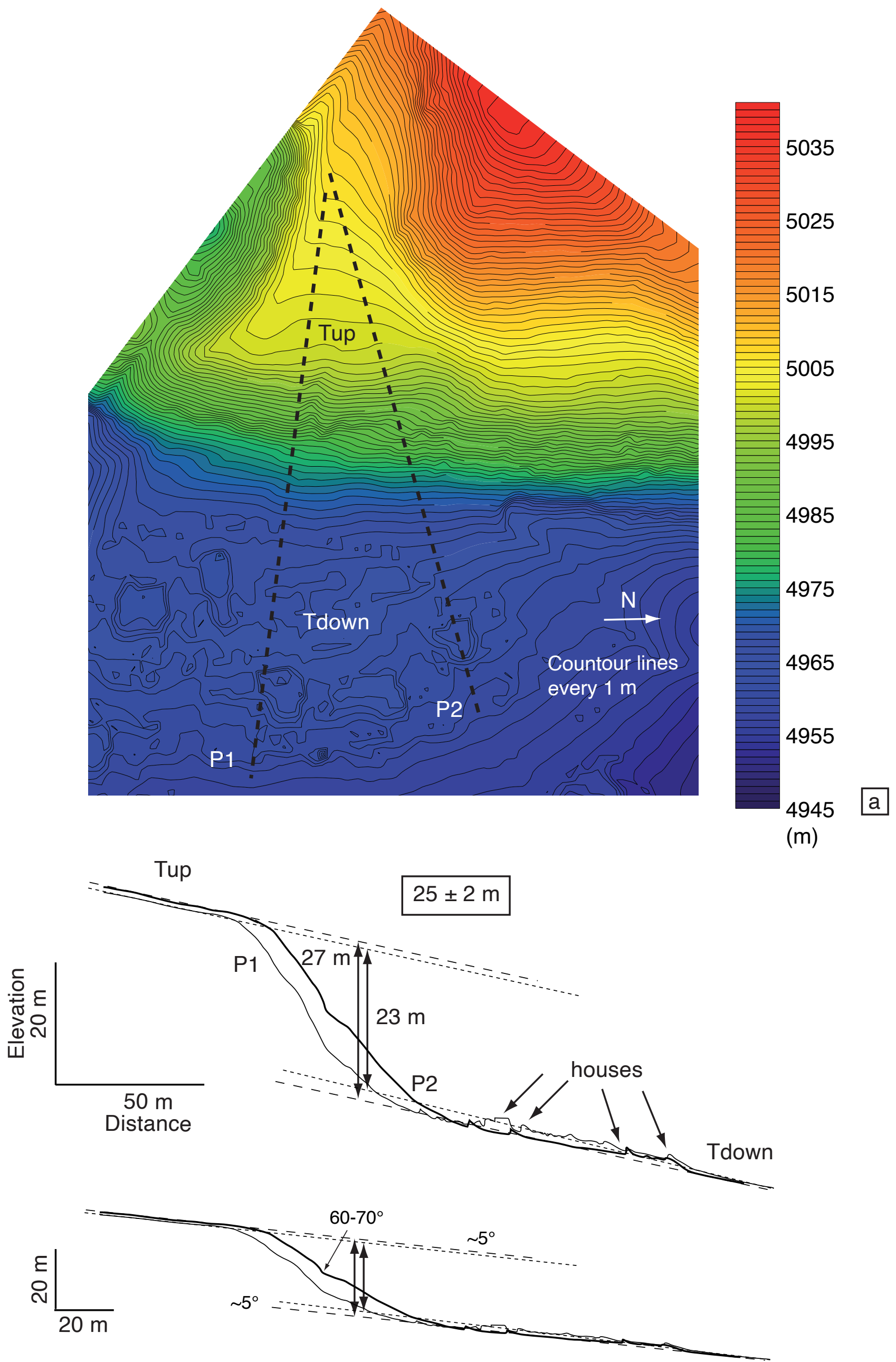
Figure 10. 


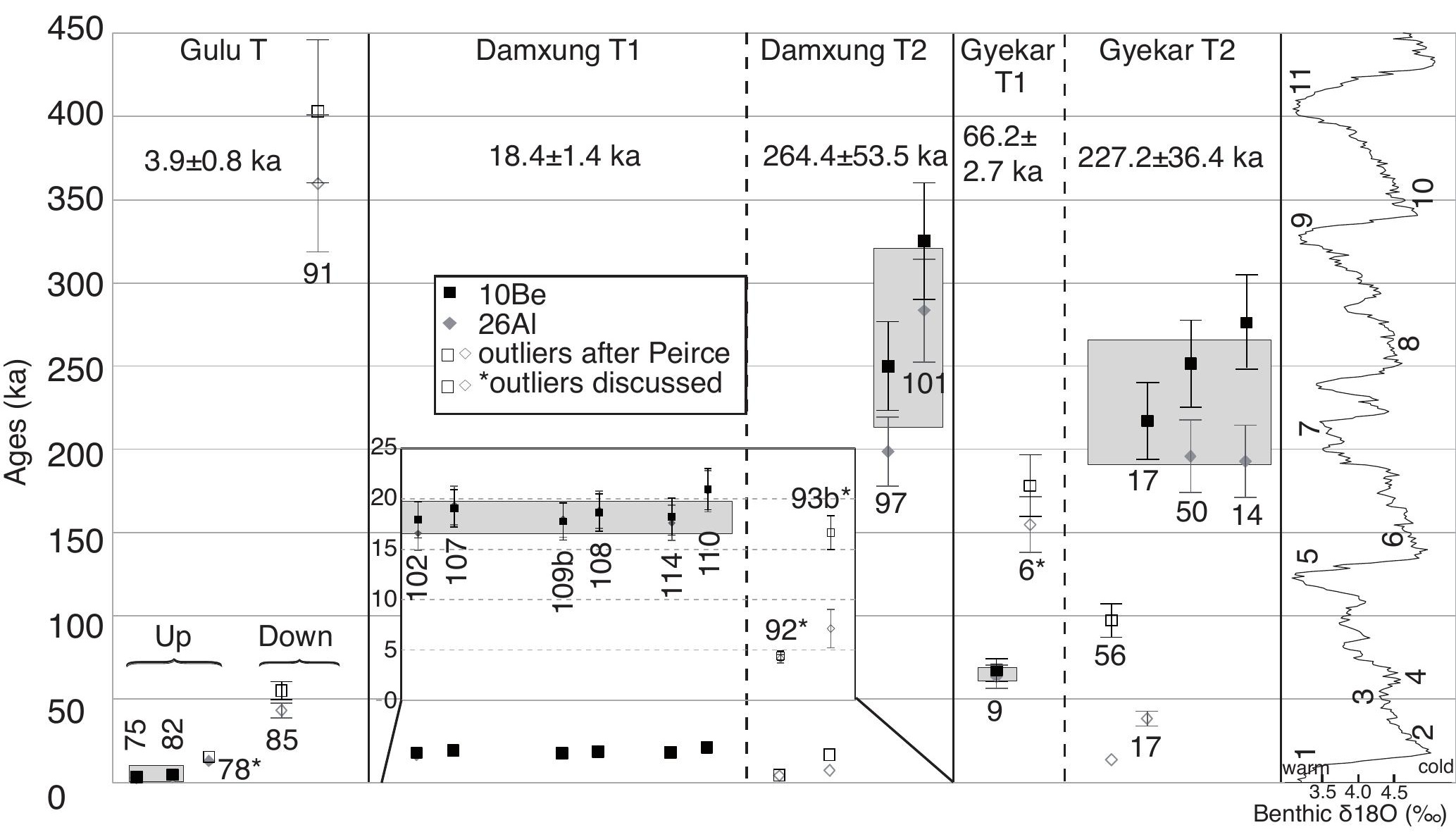


Figure 11. 
Figure 12. 


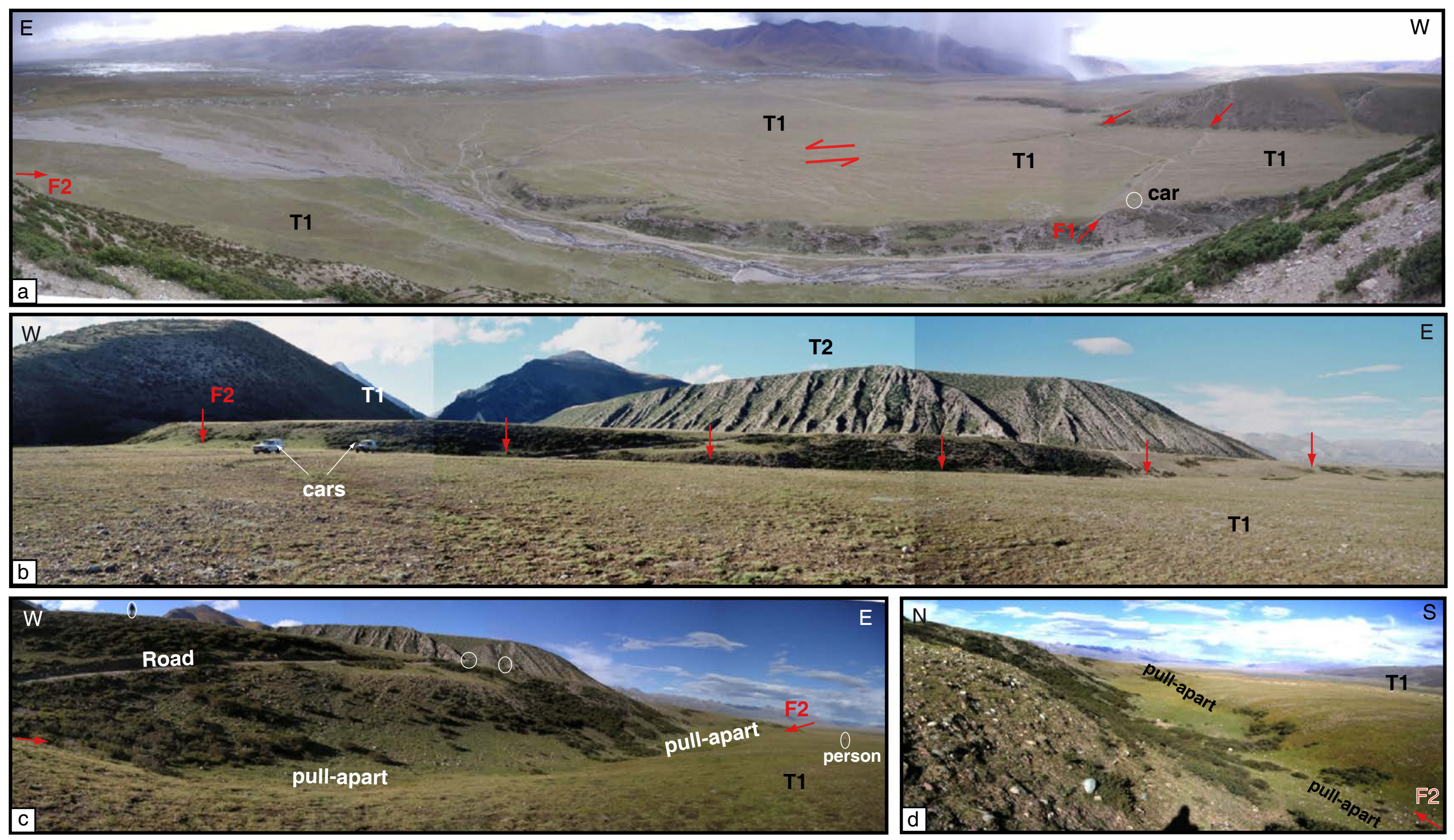


Figure 13. 

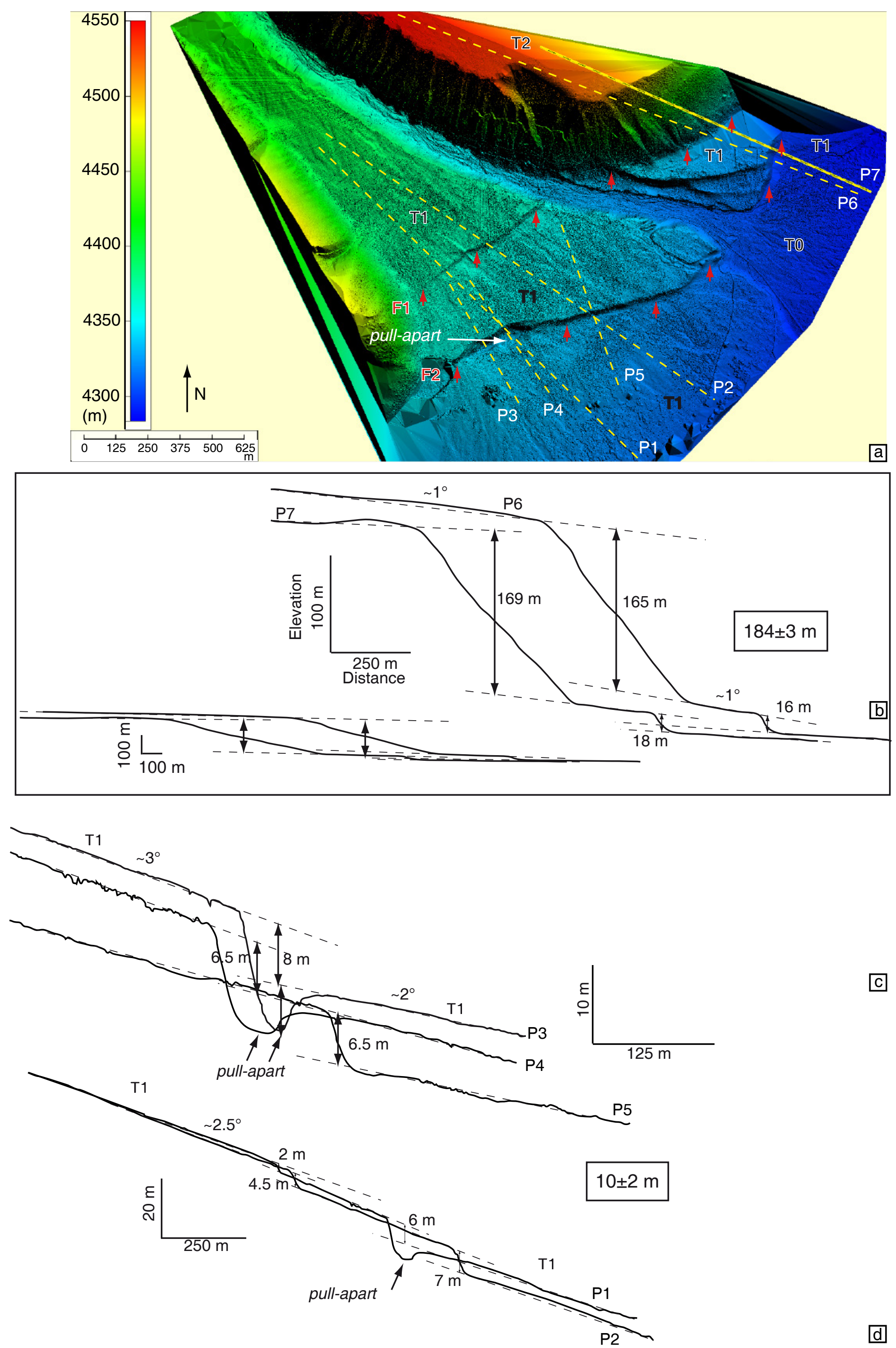
Figure 14. 

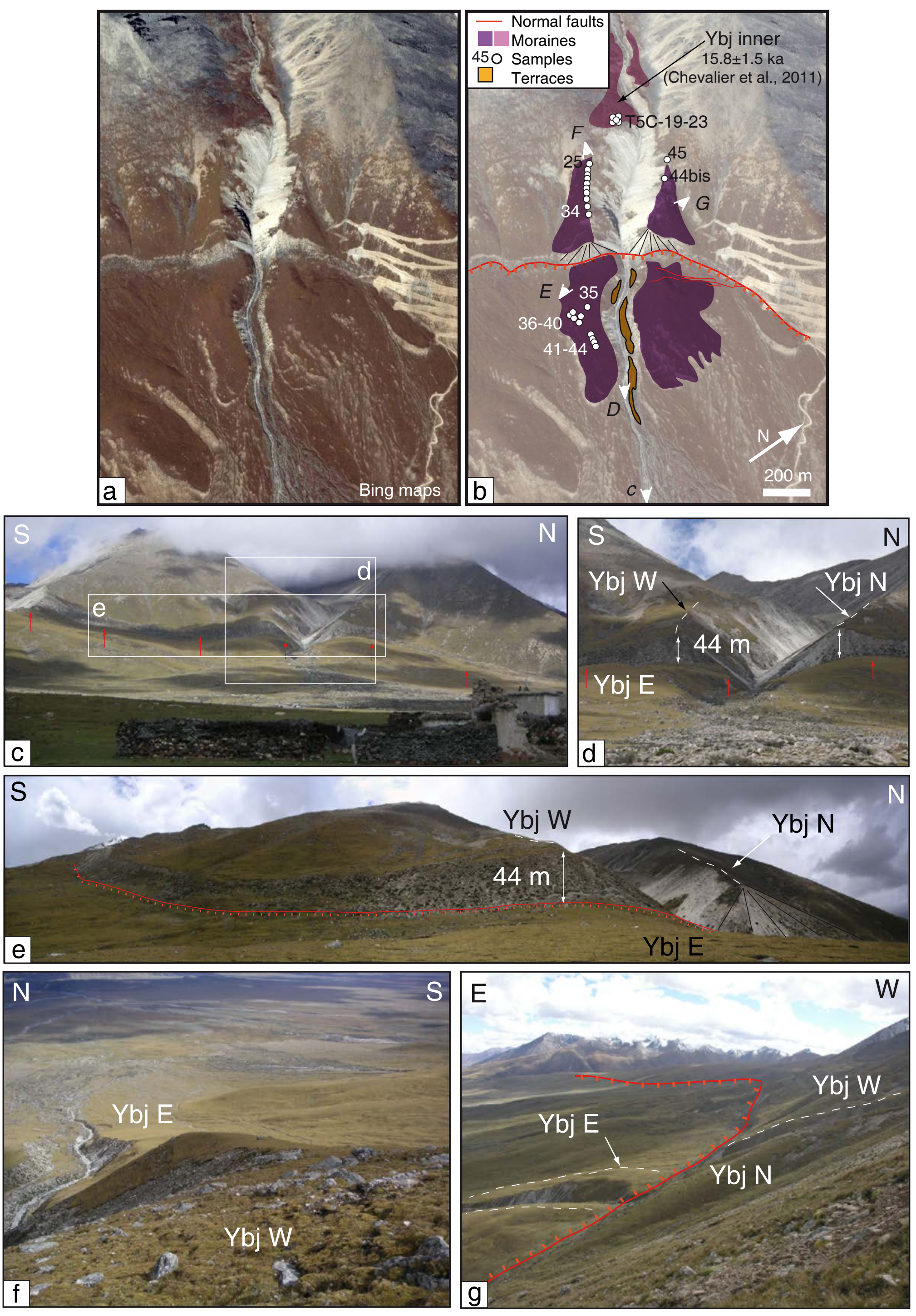
Figure 15. 


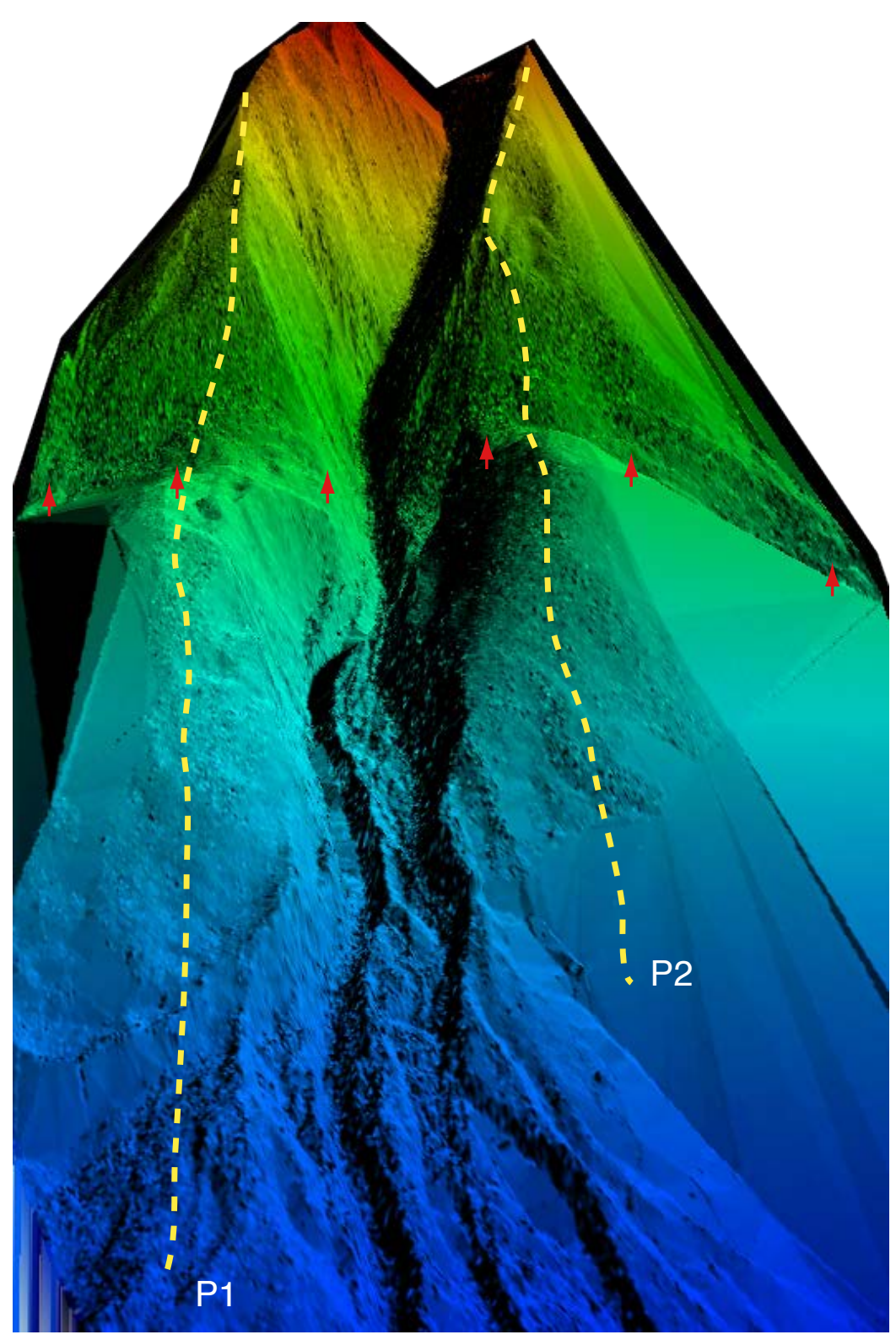

a

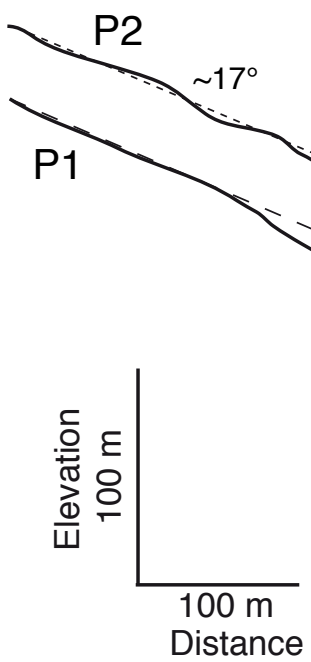

$44 \pm 1 \mathrm{~m}$ 
Figure 16. 

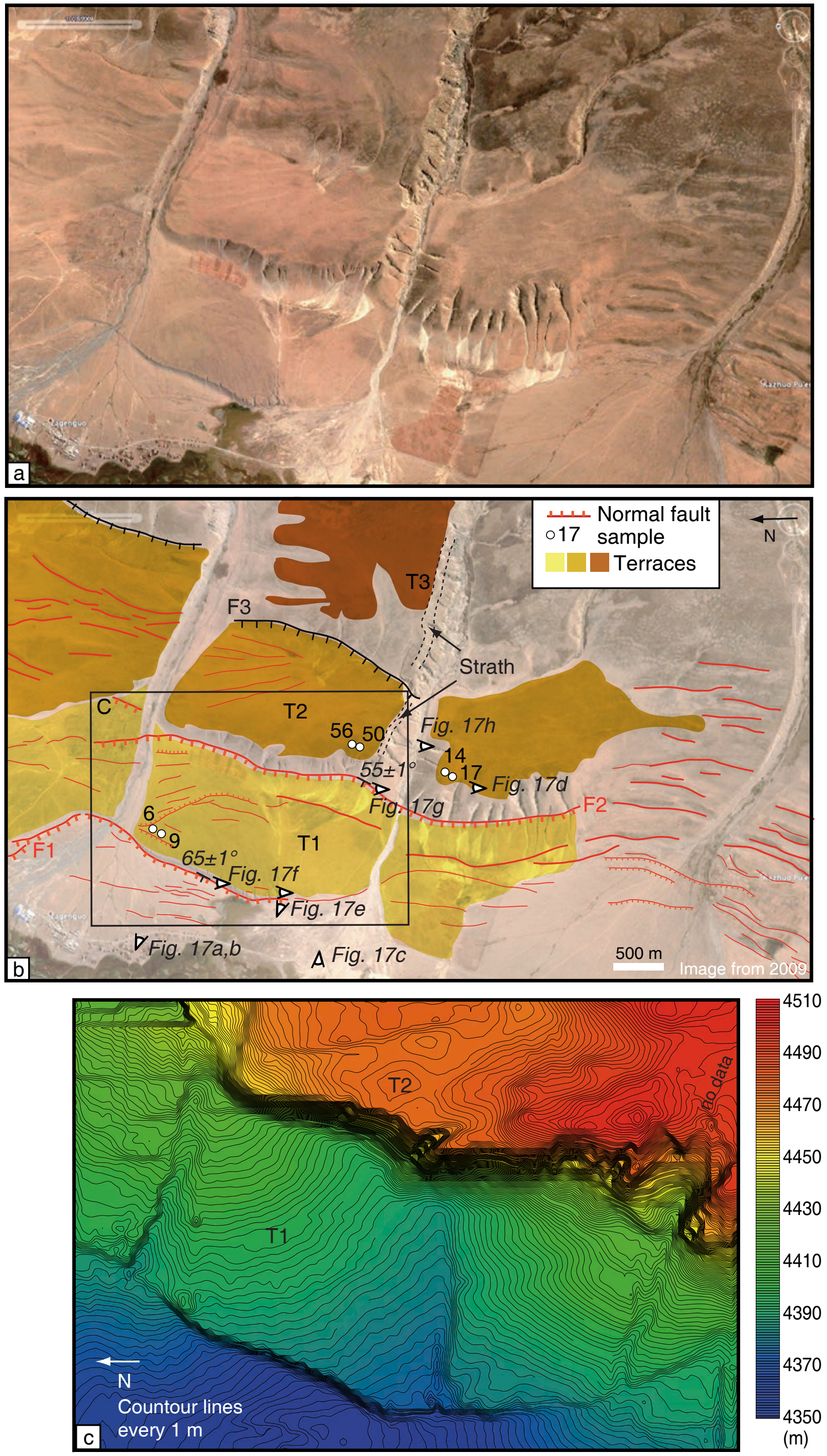
Figure 17. 

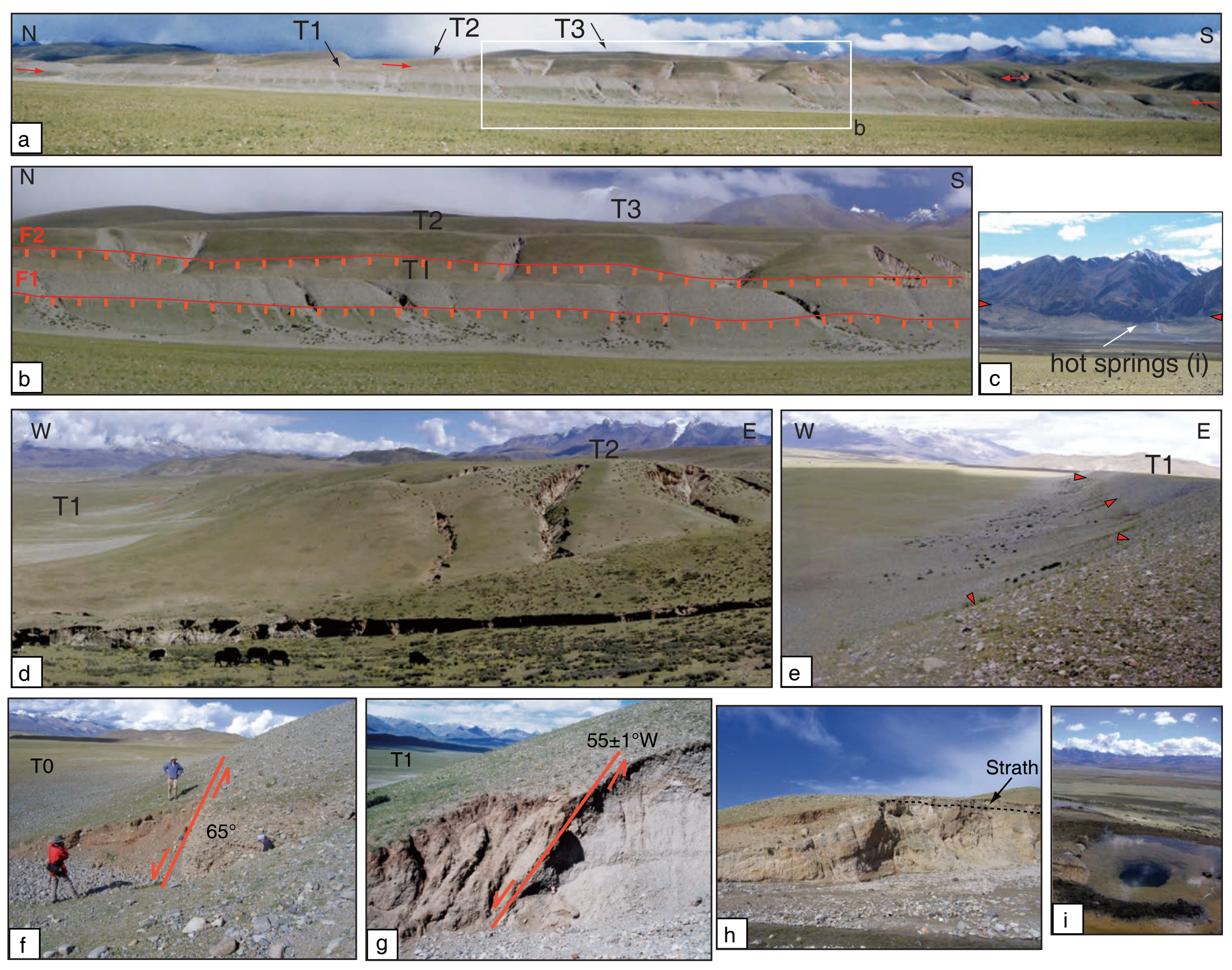
Figure 18. 

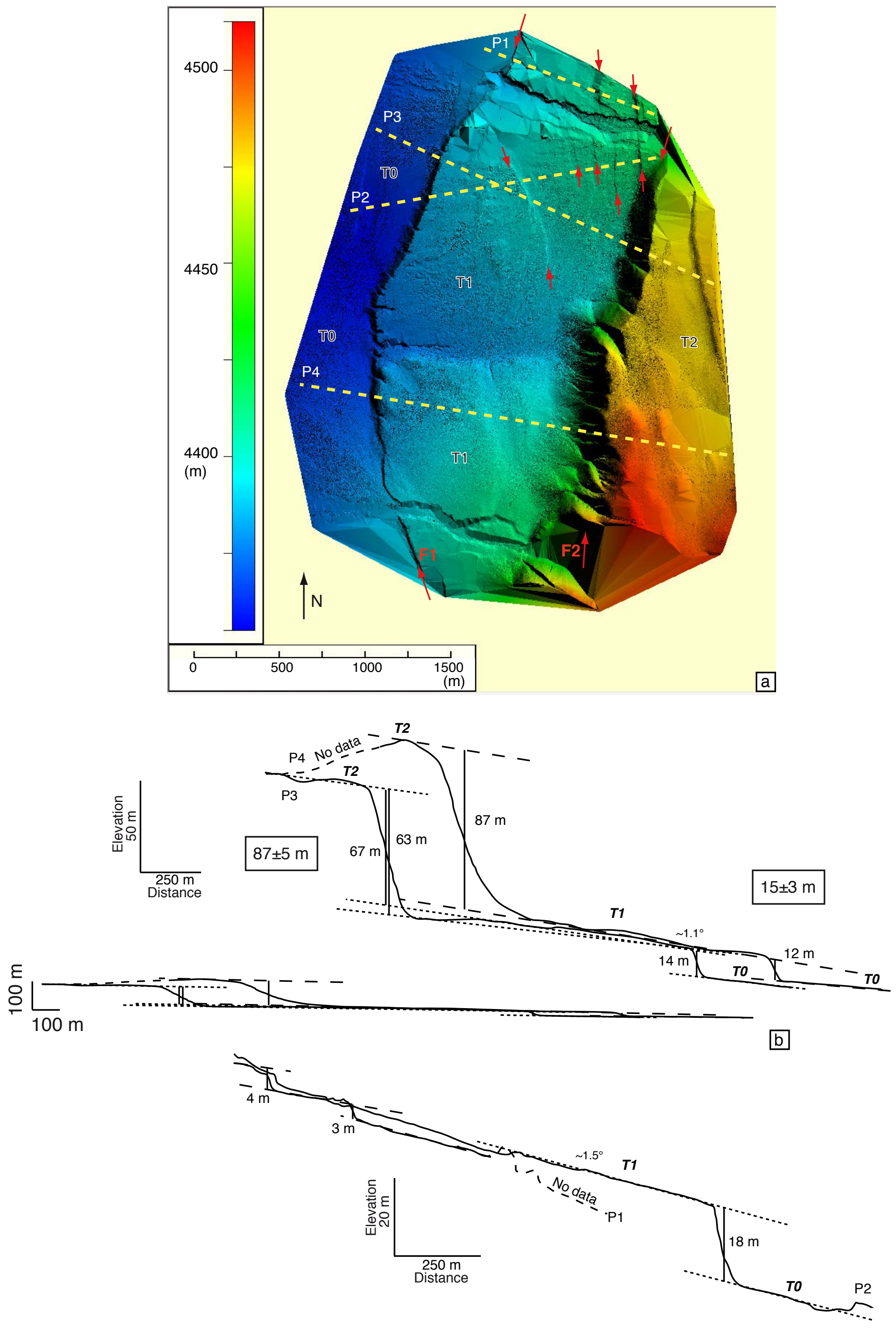
Figure 19. 

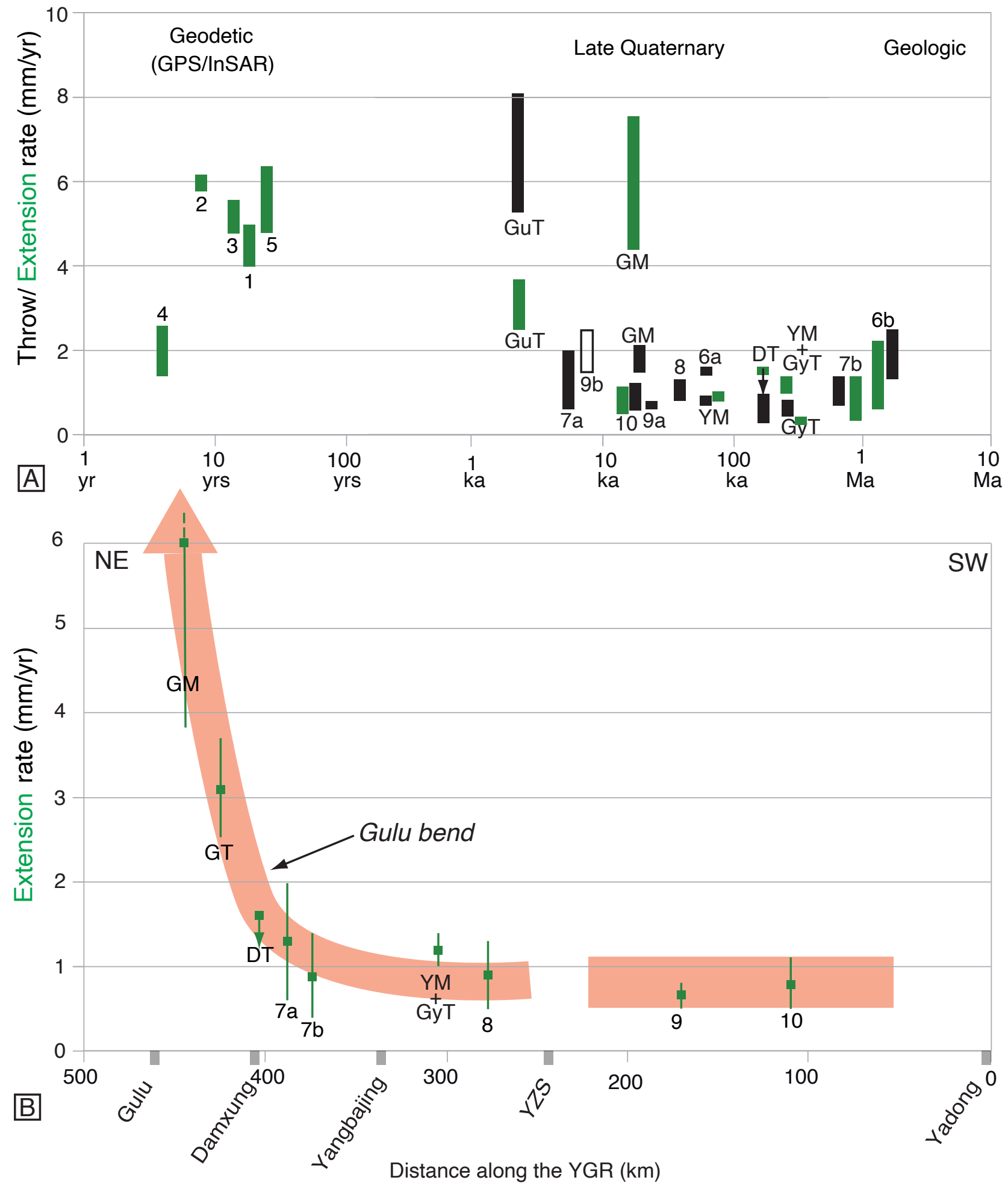
Figure 20. 


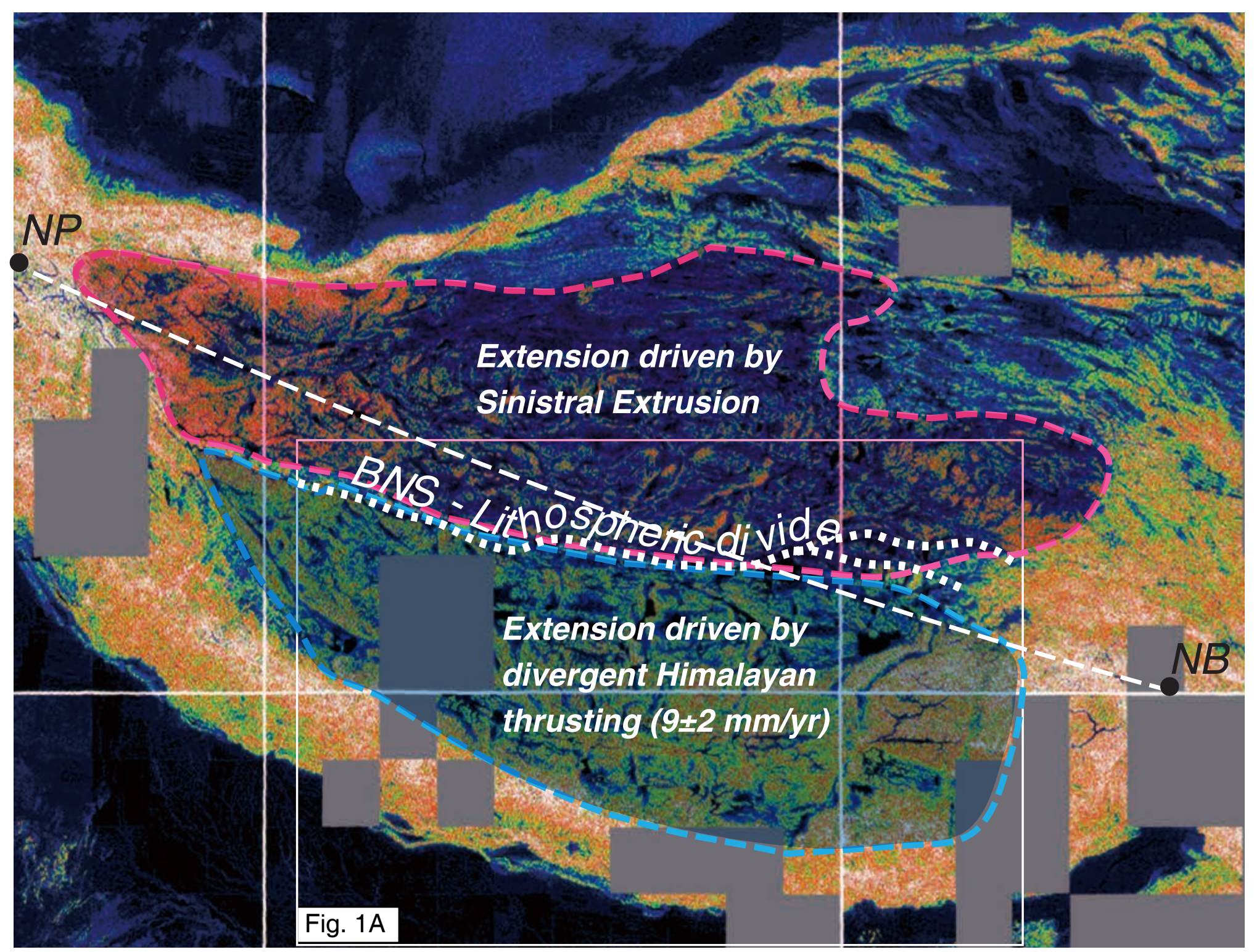

